\title{
Spatial patterns of phytoplanktonic pigments and primary production in a semi-enclosed periantarctic ecosystem: the Strait of Magellan
}

\author{
V. Saggiomo ${ }^{\text {a }}$, A. Goffart ${ }^{\text {b }}$, G.C. Carrada ${ }^{\text {c }}$, J.H. Hecq ${ }^{\text {b,d }}$ \\ ${ }^{a}$ Laboratorio di Oceanografia Biologica, Stazione Zoologica A. Dohrn, Villa Comunale, 80121 Naples, Italy \\ ${ }^{b}$ Unité d'Ecohydrodynamique, Université de Liège, Institut de Physique B5, 4000 Liège Sart-Tilman, Belgium \\ ${ }^{c}$ Cattedra di Biologia Marina, Dipartimento di Zoologia, Università di Napoli Federico II, via Mezzocannone 8, 80134 Naples, Italy \\ ${ }^{d}$ Senior Research Assistant from FNRS, Belgium
}

(Received March 22, 1993; revised and accepted November 30, 1993)

\section{Abstract}

The spatial patterns of nitrate, phytoplankton size-fractionated chlorophyll $a$, photosynthetic pigments detected by HPLC and primary production were studied at the end of the austral summer (February-March 1991), in the Strait of Magellan to provide insight into the mechanisms governing this semi-enclosed periantarctic ecosystem. Climatological peculiarities, hydrodynamic constraints, runoff and land forcing were considered.

The most important features identified for this area were the confinement of the microphytoplankton fraction to the external parts of the Strait and the rather uniform dimensional structure of the phytoplankton communities $(<5$ $\mu \mathrm{m})$ within the internal sectors. In particular, the nanoplanktonic fraction $(10-2 \mu \mathrm{m})$ comprised $33 \%$, while the picoplanktonic one $(2-0.5 \mu \mathrm{m})$ represented $62 \%$ of the total.

The concentration of active Chl. $a$ and plant pigments detected by HPLC, nitrate and primary production showed an uneven but similar distribution, allowing for the characterization of different sectors within the Strait, according to different types and intensities of forcing factors.

The different ecological sectors identified along the Strait were associated with distinct hydrographic typologies: an oligotrophic, wind-mixed coastal area, adjacent to the Pacific opening; a high runoff fjord and a divergence zone in the Andean sectors; a stratified inland sea in the basin-like part of the channel (Paso Ancho) and a shallow, tidally mixed system in the Patagonian sectors.

Areas of relatively low and high phytoplankton biomass and primary production alternate along the Strait, according to the hydrographic structures of the different sectors. Phytoplankton biomass, in terms of active Chl. $a$ (spectrofluorometric determination) ranged between 10 and $51 \mathrm{mg} \mathrm{m}^{-2}$ and primary production between 275 and $1170 \mathrm{mg} \mathrm{C} \mathrm{m}^{-2} \mathrm{~d}^{-1}$.

The assemblage of plant pigments detected by HPLC indicated that the high levels of phytoplankton pigments and production were most likely attributable to Chlorophytes, Prasinophytes, Prymnesiophytes and/or Gyrodinium and Gymnodinium-like Dinoflagellates that were submitted to natural senescence and to superfluous feeding activity; while, when Diatoms, Cryptomonads and Prymnesiophytes were dominant, efficient zooplankton grazing occurred and characterized a balanced food chain.

The spatial distribution of the parameters considered was related to hydrologic conditions indicating a Pacific water influence in the entire channel. 


\section{Introduction}

Within the framework of the Italian National Research Program in Antarctica (PNRA), and with the official collaboration of the Belgian Scientific Research Program on Antarctica, an oceanographic cruise was carried out in the Strait of Magellan from February 20 to March 3, 1991, on board $R / V$ Cariboo. The general aim of the cruise was to provide an initial assessment of the role of plankton communities in this peculiar area.

The Strait of Magellan (Fig. 1) is a $550 \mathrm{~km}$ long channel located at the tip of the South American Continent, between Southern Patagonia and Tierra del Fuego. The Strait has a V shape and shows a rich variety of physiographic features. Along the Andean arm of the V, extending from the Pacific opening to Cape Froward, the morphology of the channel changes sharply. It becomes narrower with a highly complex coast line, indented by numerous fjords and secondary channels leading to land locked embayments or, on the southern shore, to a complex web of waterways ending up in the Pacific. The bottom of the Andean branch is characterized by a variable profile, which roughly identifies two subbasins (Fig. 2). The first sub-basin, from the Pacific opening to Carlos III Island, shows depths ranging from the $60 \mathrm{~m}$ of the sill located at the Pacific opening to the considerable depths, down to $1100 \mathrm{~m}$, of its central part and up again to 64 $\mathrm{m}$ at the sill located nearby Carlos III Island. The second sub-basin occupies the channel section between Carlos III Island and Cape Froward, with depths reaching $500 \mathrm{~m}$, and is connected to the Pacific Ocean by Barbara Channel, Seno Pedro and Magdalena Channel. East of Cape Froward, the Patagonian branch includes the Punta Arenas basin, the widest part of the channel, with a width of $32 \mathrm{~km}$, a length of $119 \mathrm{~km}$ and a depth of $200 \mathrm{~m}$. The easternmost part of this branch presents an alternating series of emJayments and narrows, both characterized by ather shallow depths between 30 and $50 \mathrm{~m}$. It ends up at the Atlantic opening, $27 \mathrm{~km}$ wide.

From the climatological point of view, the Strait of Magellan may be divided, again, in two markedly different sections: from Cape Pilar to Cape Froward, the first, and from Cape Froward to Pta Dungeness, the second. The first one (Andean section) is subjected to strong land forcing due to heavy rainfalls (400 to $2000 \mathrm{~mm} / \mathrm{yr}$; Medeiros and Kjerfve, 1988) and to widespread runoff. This section is characterized by strong W-SW winds, with maximum speeds of $27 \mathrm{~m} / \mathrm{s}$ and a high frequency of cloudy days $(>8 / 10)$ and consequent low irradiance. The mentioned presence of a shallow sill $(64 \mathrm{~m})$ just west of Carlos III Island helps in generating a complex hydrographic regime. The Patagonian section presents a lower rainfall regime, from 250-300 $\mathrm{mm} /$ year (Medeiros and Kjerfve, 1988) and, hence, a reduced runoff.

The literature on the hydrology of the Strait is scanty, fragmentary and restricted to a few contributions (Pickard, 1971, 1973; Chuecas, 1980; Medeiros and Kjerfve, 1988; Michelato et al., 1991; Panella et al., 1991). These authors contributed to a general picture of the thermohaline characteristics of the Strait and proposed a hydrological division of the channel according to the presumed origin of the inflowing water masses.

On the basis of a broad oceanographic description of some inlets of the Strait, Pickard (1971) suggested that the Atlantic Ocean is the source of the water for the Patagonian branch of the channel, the inlets of the south-eastern part of the Strait and the Andean section until Carlos III Island and Seno Otway.

Along the axis of the Strait, during the austral spring (November 1989), Panella et al. (1991) identified three main hydrological sub-basins. The western one extended from the Pacific entrance to Carlos III Island. A moderate thermocline and a well-defined halocline, due to significant input of fresh water, characterized the upper layer ( $S$ $=28.0-32.5$ PSU for the 0-100 m layer). Below the halocline, a strong Pacific influence was observed. The central sub-basin, from Carlos III Island to Paso Ancho, presented a water mass generated by the mixing of Atlantic water with continental runoff and glaciofluvial water. In the eastern sub-basin, lying from the Second Narrow to the Atlantic entrance, the strong influence 


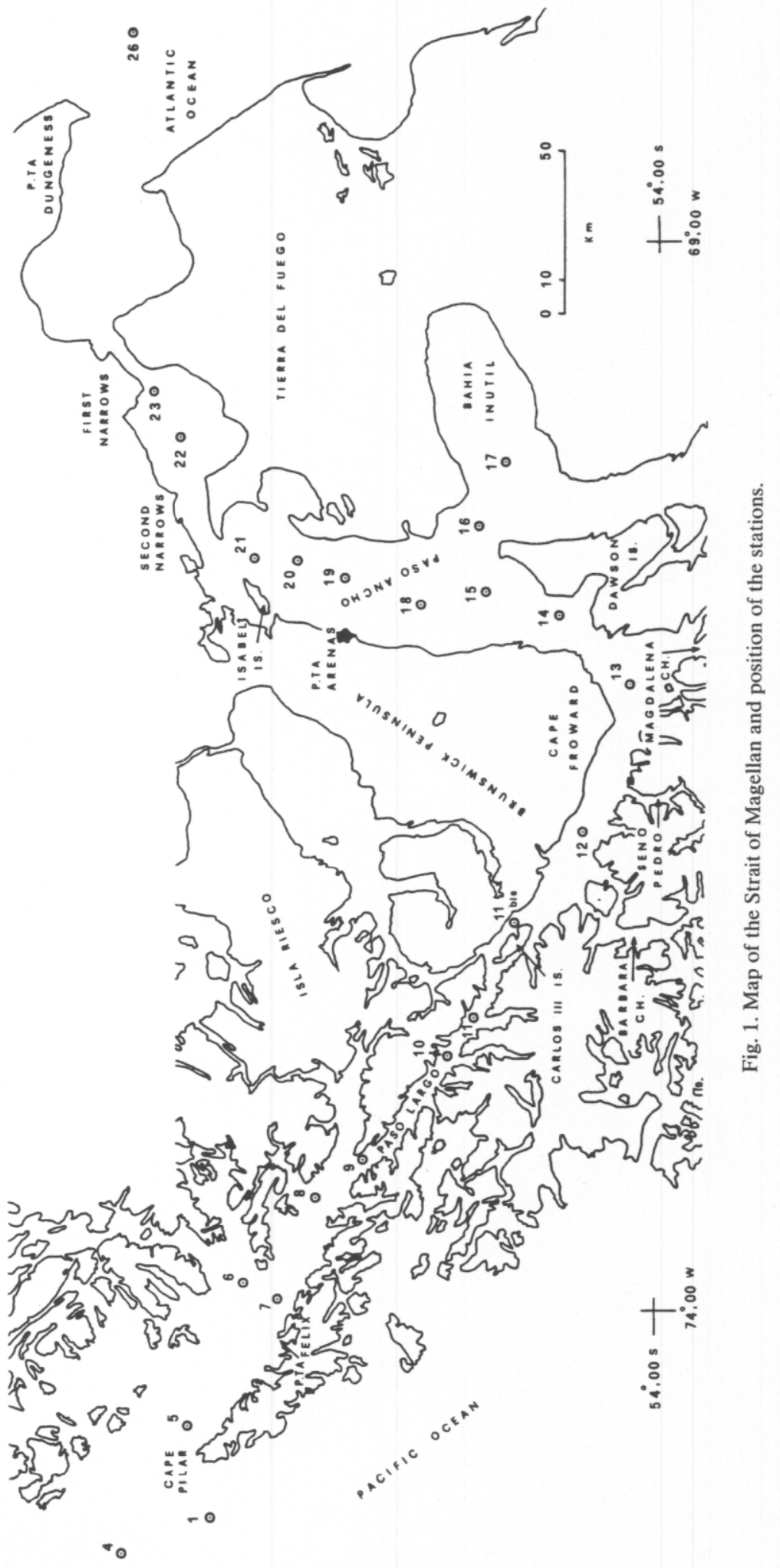


exerted by the intense tidal currents resulted in the mixing of Atlantic and more diluted internal waters.

At the Atlantic entrance, Michelato et al. (1991) report a homogeneous water column $(T=$ $6^{\circ} \mathrm{C}, S=32.5$ PSU) and Medeiros and Kjerfve (1988) indicate that tidal currents were strong, with mean amplitudes of $7.1 \mathrm{~m}$.

According to Michelato et al. (1991), proceeding westward of the Atlantic opening, the tidal range is initially amplified to $8.4 \mathrm{~m}$ by the geometry of the first embayments and reduces progressively to $1.2 \mathrm{~m}$ in Paso Ancho. On the Pacific side, tides have a mean range of $1.1 \mathrm{~m}$. Below 40 $\mathrm{m}$, residuals currents indicate a weak long-term transport from the Atlantic opening into the Strait. To the present the problem of the origin of the waters of the Strait of Magellan is still open.

It is important to note that Glorioso (1987) reports, during the austral summer, the presence of cold and low salinity waters of Magellan origin in the Gulf of San Jorge, some 400 miles north of the Atlantic opening of the Strait.

Some papers deal with the floristic composition of the phytoplankton of the Strait (Lembeye et al., 1978; Lembeye, 1981; Uribe, 1991) or report localized events of toxic phytoplankton blooms (Campodónico et al., 1975; Guzmán et al., 1975; Lembeye et al., 1975; Uribe, 1988a; b).

Phytoplankton pigment distributions along the entire channel are given by Panella et al. (1991) for the austral spring 1989. Low levels $(<1 \mu \mathrm{g} / \mathrm{l})$ of total chlorophyll $a$ (Chl. a) were observed in the Pacific sub-basin. The richest area, in terms of total Chl. $a$, extended, in the central sub-basin, from Carlos III Island to Paso Ancho. Maximum values of total Chl. $a(>7 \mu \mathrm{g} / \mathrm{l})$ occurred east of Cape Froward. Along the axis of the Strait, the largest percentage of Chl. $a$ was found in the micro- and nano-phytoplankton $(>2 \mu \mathrm{m})$. The picophytoplankton fraction $(<2 \mu \mathrm{m})$ followed a similar pattern to the other fractions but showed much lower levels $(<0.6 \mu \mathrm{g} / \mathrm{l})$.

Iriarte et al. (1993) describe the phytoplankton composition and the concentration of Chl. $a$ for different size-fractions, during the spring-summer 1990-1991, at four stations, two of which located in the inlets of the northern shores in the vicinity of the Pacific opening and two in the Strait proper.

The objective of this paper is to describe the structure of the summer phytoplankton communities in the Strait of Magellan and to gain from these some insight into the possible influence of oceanic water on the pelagic communities of the Strait. The effects of climatological peculiarities, runoff and land forcing are considered.

To this purpose, spatial patterns of phytoplankton pigments and primary production were investigated along a west-to-east transect, in relation with nitrate concentrations and water density distributions. Size-fractionated Chl. $a$ and pigments detected by HPLC are used as indicators

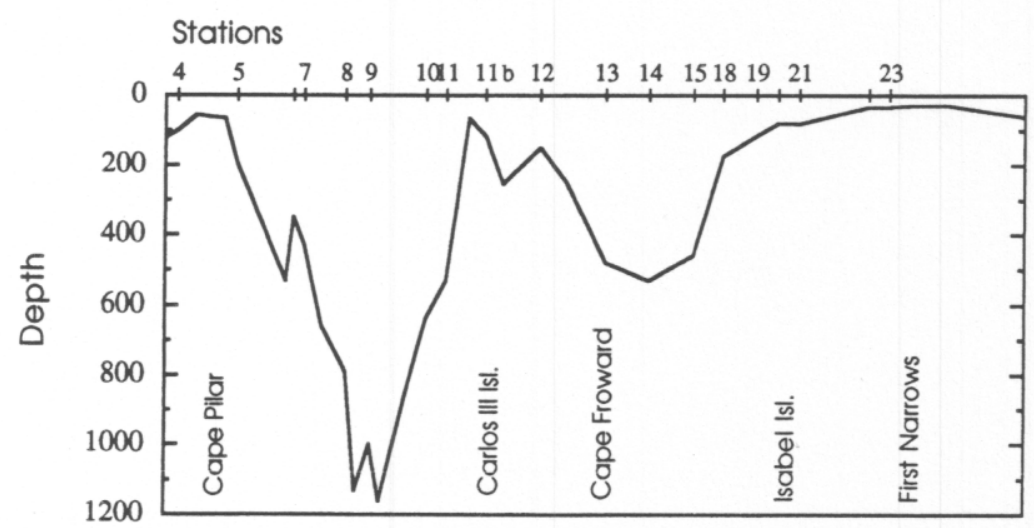

Fig. 2. Bottom topography along the axis of the Strait of Magellan. 
of phytoplanktonic biomasses and biotracers of water masses. Specific HPLC phytopigments and Chl. $a$ degradation products are utilized respectively as chemotaxonomic markers and tracers of processes involved in the degradation of phytoplankton.

The Italian and Belgian contribution to the physical, chemical and biological oceanography of the Magellan Strait is collected in a special issue of the Bollettino di Oceanologia teorica e applicata (vol. 9, 1991), devoted to the results of the $\mathrm{R} / \mathrm{V}$ OGS Explora, carried out in the Strait of Magellan in October-November 1989, in Anonymous (1991), in Magazzù (1991) and in Faranda and Guglielmo (1993). Magazzù (1991) represents the proceedings of a workshop on Subantarctic Areas held in October 1991, formally dated 1991, printed in November 1992 but made available in 1993.

\section{Materials and methods}

The sampling protocol was designed to provide the most detailed spatial information compatible with the other research activities on board, and taking into consideration both the horizontal and the vertical dimensions. The horizontal dimension was covered with surface samples collected by continuously pumping sea water in the laboratory from an intake located in the bow section of the ship hull at $-2 \mathrm{~m}$. Samples were collected at about 2.5 miles intervals, in order to provide a screening of the area sufficient to resolve small scale dynamics, along a track compatible with navigation necessities and safety limitations. A total of 152 sampling points was obtained. Surface samples were utilized for the determination of active Chl. $a$ content of size fractionated phytoplankton.

Vertical sampling was carried out on a series of hydrographic stations (Fig. 1) by means of a General Oceanic rosette, equipped with a set of 12 Niskin bottles of 101 capacity, a Neil Brown MK III CTD system and a Sea-Tech Fluorometer. For St. 26, located in the Atlantic shelf about 4 miles from the Strait entrance, only surface data are available, as during operations the sampler was lost at sea.
The sampling depths were selected according to optical levels identified using a Li-Cor underwater quantameter and at hydrographic levels down to $100 \mathrm{~m}$ wherever allowed by the station depth.

At each station, samples were collected for the measurement of nitrate concentrations, of Chl. $a$ content of size-fractionated phytoplankton, of plant pigments determined by HPLC and of primary production.

The surface samples for active Chl. $a$ determination were subjected to serial filtration on 2 and $1 \mathrm{~mm}$ polycarbonate Nuclepore membranes and $0.5 \mu \mathrm{m}$ fiber glass $\mathrm{GF} / \mathrm{F}$ filters. The samples collected at the hydrographic stations were sequentially filtered on 10,2 and $0.2 \mu \mathrm{m}$ Nuclepore membranes and differentially filtered on $2,1 \mu \mathrm{m}$ Nuclepore membranes and $0.5 \mathrm{~mm}$ fiber glass $\mathrm{GF} / \mathrm{F}$ filters. All filters were immediately stored at $-25^{\circ} \mathrm{C}$.

Spectrofluorometric determination of Chl. a concentrations were carried out one month later. Photosynthetic pigments were extracted in neutralized $90 \%$ acetone after grinding and analyzed by means of a Perkin Elmer LS 50 spectrofluorometer before and after acidification, according to the procedure suggested by Turner Designs (Anonymous, 1981). Five readings were performed per sample, each reading with an integration time of three seconds. Excitation and emission wavelengths were selected on the basis of a prescan on a solution of Chl. $a$ from Anacystis nidulans (Sigma) performed before carrying out each set of analyses (about 40 samples). The values obtained were always $432 \mathrm{~nm}$ for excitation, and $668 \mathrm{~nm}$ for emission.

The determination of the primary production of the phytoplankton size fractions was done according to the methods described by Saggiomo et al. (1990) and Magazzù and Decembrini (1990). In particular, optical depths $(100,50,22.5,8,3.5$ and $1.7 \%$ of surface radiation) were determined using a Li-cor underwater quantameter (wavelength 350-700 $\mathrm{nm})$ and total PAR $\left(\mathrm{E} \mathrm{m}^{-2} \mathrm{~h}^{-1}\right)$ was measured on deck by means of a Quantum Sensor Li-cor $550 \mathrm{LI}$ integrator during the entire cruise period. The measurements of production were carried out whenever compatible with the 
other research activities on board, for 4 hours, between 9 a.m. to 5 p.m., mostly around noon time. Within $10 \mathrm{~min}$ from their arrival on deck, samples were subdivided, for each level, into two $450 \mathrm{ml}$ polycarbonate (Nalgene) bottles with $1 \mathrm{ml}$ of a $\mathrm{NaH}^{14} \mathrm{CO}_{3}$ solution having an activity of 10 $\mathrm{mCi} / \mathrm{ml}$. One of the two bottles was wrapped in aluminum foil. The samples were then placed in a deck incubator with running surface sea water in natural light conditions using neutral screens (Stork Veco) to obtain the light levels of the collection depth. After about 4 hours of exposure, the samples were filtered using both differential and sequential procedures to separate the micro- $(>10 \mu \mathrm{m})$, nano- $(10-2 \mu \mathrm{m})$ and picoplanktonic $(<2 \mu \mathrm{m})$ fractions. The filters were stored at $-25^{\circ} \mathrm{C}$ in scintillation vials and read one month later in a Beckman LS 1801 scintillator, using $10 \mathrm{ml}$ of "Aquasol" scintillation cocktail. Daily production was estimated multiplying the ratio between the whole day irradiance and the irradiance during the incubation period.

Samples for nitrate determination were collected at optical depths in the euphotic layer and at hydrographic depths in the remaining part of the water column. Analyses were carried out on board using an Autoanalyzer Technicon II System, after sample filtration through GF/C fiber glass filters and according to the method of Hansen and Grasshoff (1983).

Nearly all pigments and their degradation products were separated and quantified by HPLC, following a method adapted from Mantoura and Llewellyn (1983). Water samples (0.5 to 11$)$ collected at optical and hydrographical depths down to $300 \mathrm{~m}$, were filtered through $47 \mathrm{~mm}$ Whatman $\mathrm{GF} / \mathrm{F}$ filters and immediately stored at $-25^{\circ} \mathrm{C}$ until analysis, one month later. Frozen filters were extracted in $100 \%$ methanol using grinding and refiltration to remove cellular debris. An aliquot of $500 \mu \mathrm{l}$ of filtered extract was mixed with $250 \mu \mathrm{l}$ of tetrabutylammonium acetate ion pairing reagent (Mantoura and Llewellyn, 1983) and $200 \mu \mathrm{l}$ were injected into a Pharmacia LKB HPLC system. Pigments were separated by a LKB Bromma 2150 HPLC pump in a Chromspher C18 column and the separation of chlorophylls from their degradation products was optimized using a solvent gradient system (LKB 2152 LC Controller). The gradient program consisted of a linear increase from solvent A (methanol, ion pairing solution, water; $8: 1: 1)$ to solvent $\mathrm{B}$ (methanol, acetone; 7:3) in $10 \mathrm{~min}$, followed by $10 \mathrm{~min}$ in solvent B and regeneration in solvent A. Each chromatography took $30 \mathrm{~min}$. Pigments were detected at $440 \mathrm{~nm}$ by a LKD 2151 wavelength monitor. A fluorescence Milton Roy III detector was also used (excitation at $440 \mathrm{~nm}$; emission between 500 and $700 \mathrm{~nm}$ ). The chromatograms were recorded with a two-channel Spectraphysics recorder and stored on floppy disks. For pigment identification and calibration, culture and natural extracts were chromatographed by scanning spectrophotometry (Cecil 300 ) in the laboratory (Hecq et al., 1991).

\section{Results and discussion}

\subsection{Chlorophyll a}

Fig. 3 shows the distribution of incident PAR for the observation period: the Andean sector is characterized by variable and relatively low levels compared to the constantly high ones of the Patagonian sector.

Along the axis of the Strait, the horizontal pattern of total and size-fractionated ( $>2 \mu \mathrm{m}$, $<2 \mu \mathrm{m}$ and $<1 \mu \mathrm{m})$ Chl. $a$ concentrations from Pta Felix (Pacific end) to Pta Dungeness (Atlantic



Fig. 3. Incident PAR during the cruise period. 
end) is shown in Fig. 4. For each fraction, maximum, minimum, mean, standard deviation and percent values are reported in Table 1.

A gradient of increasing concentrations, with values always in excess of $1.5 \mu \mathrm{g} / \mathrm{l}$, is observed from the Pacific opening to the eastern side of Carlos III Island. A drastic decrease of concentrations $(<1 \mu \mathrm{g} / \mathrm{l})$ then follows and persists up to Cape Froward; another increasing gradient takes place henceforth and culminates in the area
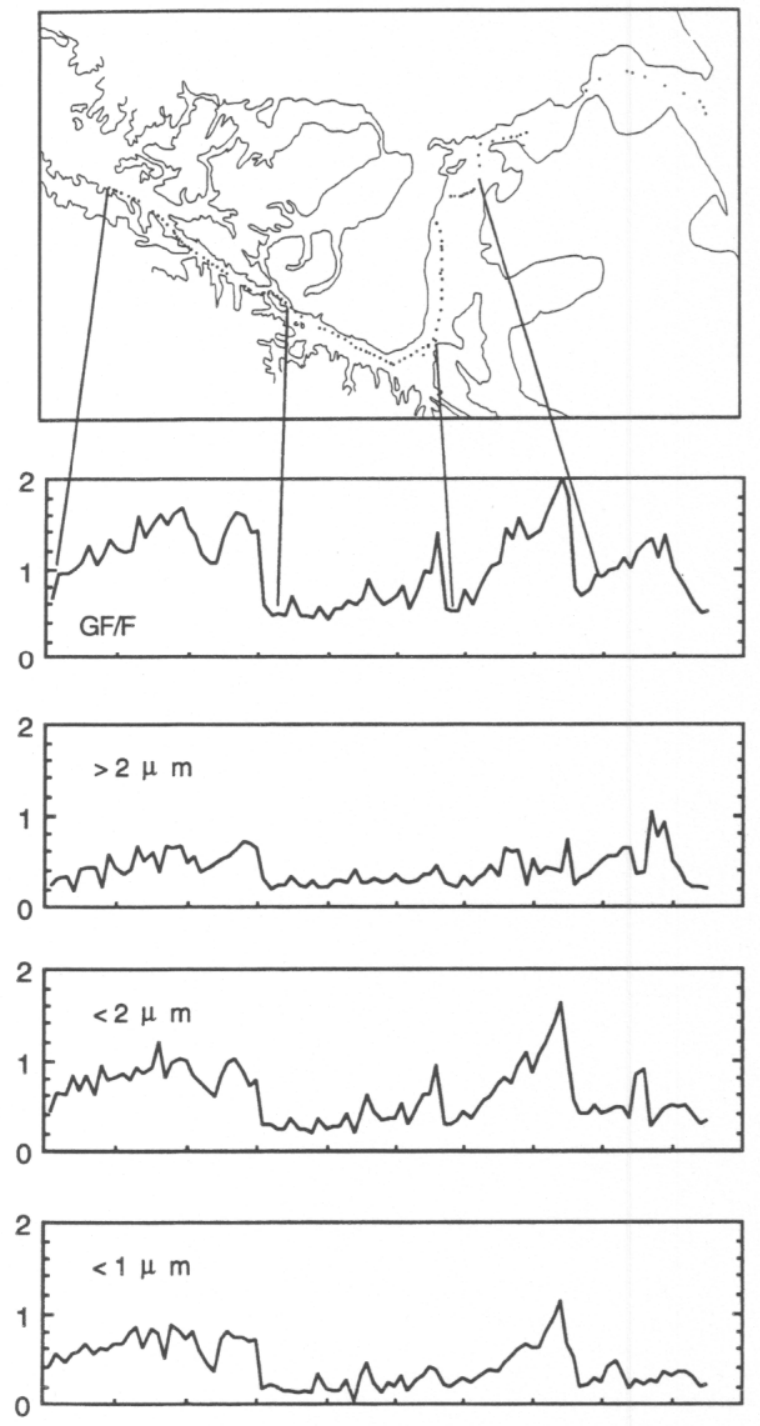

Fig. 4. Horizontal distribution $(\mu \mathrm{g} / \mathrm{l})$ of size-fractionated chlorophyll $a$ along the axis of the Strait of Magellan. of Paso Ancho, in front of Punta Arenas. The richest area in terms of total Chl. $a$ concentrations, with values above $2 \mu \mathrm{g} / \mathrm{l}$, is that of Paso Ancho, where the channel widens out into a broad basin characterized by a pronounced spatial heterogeneity (Fig. 5). For this area, maximum, minimum, mean, standard deviation and percent values for size fractions are reported in Table 2 .

High total Chl. a concentrations ( $>1 \mu \mathrm{g} / \mathrm{l})$ are also present in the eastern part of the Strait, which is separated from the Paso Ancho basin by a sharp spatial discontinuity located at the western end of the Second Narrows (St. 21). The Atlantic opening shows the lowest values, less than $0.8 \mu \mathrm{g} / \mathrm{l}$.

Averaged for all samples, except those of the eastern area of the Strait, the $<1 \mu \mathrm{m}$ fraction accounts for more than $67 \%$ of total picoplankton. This fraction cannot be ascribed only to Procaryotes, namely Cyanobacteria, as Marino et al. (1991) have shown, for the same cruise, the presence of very small eucaryotic cells that could easily escape through a $1 \mu \mathrm{m}$ filter.

The vertical distribution of Chl. $a$ of total, micro-, nano- and picophytoplankton in twelve stations located along the axis of the Strait is shown in Fig. 6. Integrated values for the euphotic zone (1\% of incident PAR) and their percent contribution of each fraction is reported in Table 3.

Proceeding eastward from the Pacific end, areas of high pigment content can be identified in Paso Largo (St. 9, 10 and 11 Bis), in Paso Ancho (St. 14, 18 and 20) and in the embayment between the First and the Second Narrows (St. 22 and 23). Areas characterized by a lower Chl. a content occur between the eastern side of Carlos III Island and Cape Froward (St. 12 and 13) and at St. 4 (Pacific opening). Stations $11 \mathrm{Bis}$ and 21 indicate two zones of discontinuity.

It is noteworthy that the microplanktonic fraction is confined to the Pacific opening (St. 4) and to the embayment between the two Narrows (St. 22 and 23) where it reaches percentages of 31.6, 38.9 and 60.5 respectively, while in the remaining part of the channel this fraction is always less than $6 \%$. The nano- and picoplanktonic fractions 
Table 1

Fractionated chl. $a(\mu \mathrm{g} / \mathrm{l})$ along the axis of the Strait

\begin{tabular}{llccc}
\hline & Tot GF $/ \mathrm{F}$ & $>2 \mu \mathrm{m}$ & $<2 \mu \mathrm{m}$ & $1 \mu \mathrm{m}$ \\
\hline Min. & 43 & 0.16 & 0.17 & 0.03 \\
Max. & 2.00 & 1.04 & 1.63 & 1.13 \\
Mean & 1.01 & 0.41 & 0.60 & 0.42 \\
St. dev. & 0.39 & 0.17 & 0.30 & 0.24 \\
$\%$ & & 41.26 & 58.74 & 40.19 \\
\hline
\end{tabular}

Table 2

Fractionated chl. $a(\mu \mathrm{g} / \mathrm{l})$ in Paso Ancho

\begin{tabular}{llccc}
\hline & Tot GF $/ \mathrm{F}$ & $>2 \mu \mathrm{m}$ & $<2 \mu \mathrm{m}$ & $<1 \mu \mathrm{m}$ \\
\hline Min. & 0.76 & 0.14 & 0.42 & 0.23 \\
Max. & 2.54 & 0.85 & 1.71 & 1.35 \\
Mean & 1.55 & 0.48 & 1.07 & 0.70 \\
St. dev. & 0.41 & 0.16 & 0.30 & 0.26 \\
\% & & 30.99 & 69.01 & 45.33 \\
\hline
\end{tabular}
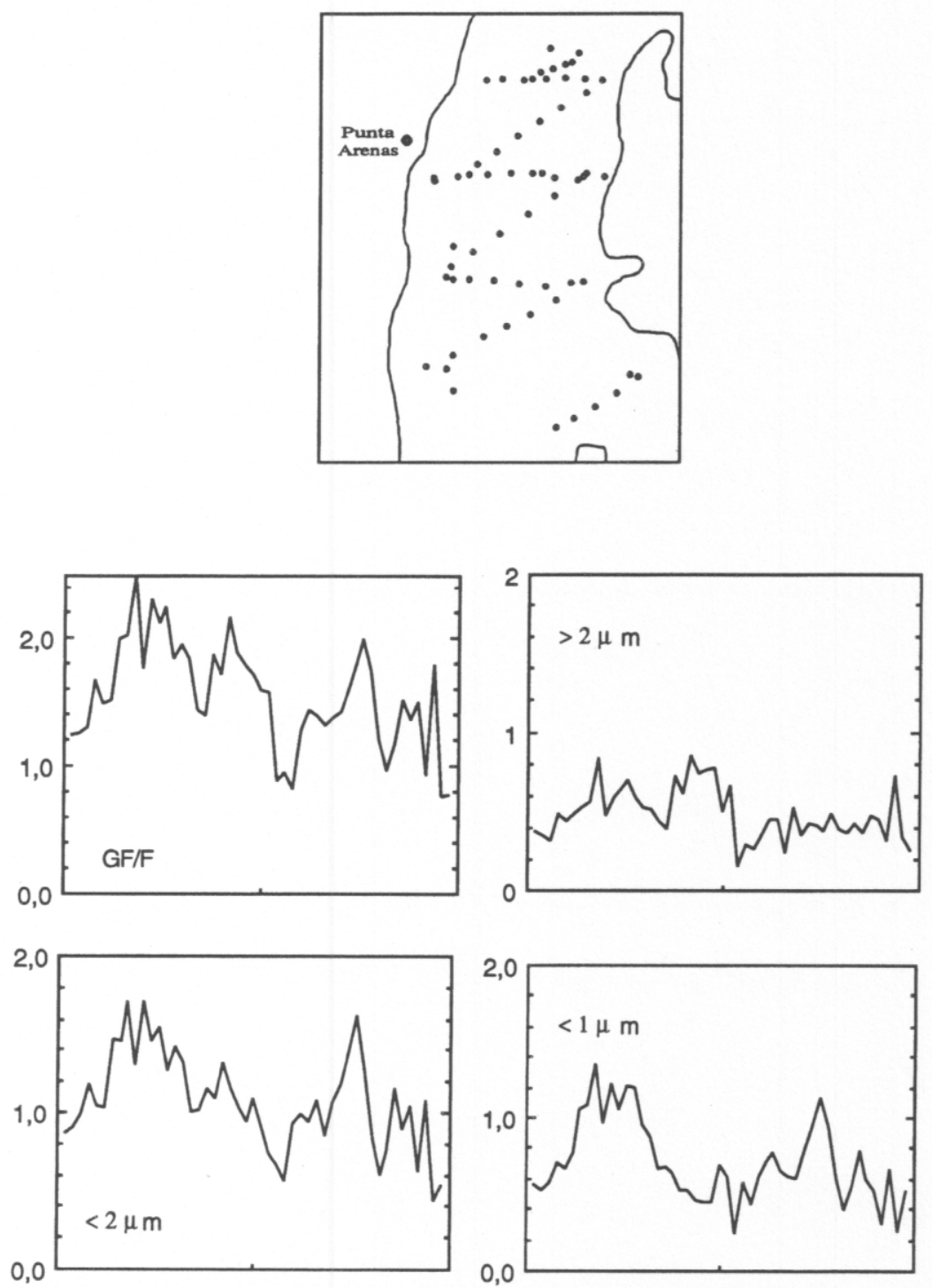

Fig. 5. Horizontal distribution $(\mu \mathrm{g} / \mathrm{l})$ of size-fractionated chlorophyll $a$ in the Paso Ancho basin. 
characterize the entire length of the Strait with a mean of $33 \%$ and $62 \%$ of the whole community, respectively.

The horizontal and vertical distributions of size fractionated and total Chl. $a$ identify clear-cut spatial patterns, on the basis of which the Strait of Magellan can be divided in five sectors:

the sill area at the Pacific opening (A);

from P.ta Felix to Carlos III Island (B);

from Carlos III Island to Cape Froward (C);

from Cape Froward to Isabel Island (D);

from Isabel Island to P.ta Dungeness (E).

Marked dimensional differences exist between the two external sectors of the Strait (A and E), while the more internal ones are characterized by a rather uniform percent distribution of the fractions considered. In fact, in the sectors B, C and $\mathrm{D}$, the microplanktonic fraction never exceeds $6 \%$ of the total biomass, while the same fraction comprises $32 \%$ in sector $\mathrm{A}$ and $50 \%$ in sector $\mathrm{E}$. In addition, the vertical distribution of the sizefractions (Fig. 7) shows that, except for St. 4, 22 and 23 , the depth variations of phytoplankton biomass are due to the picoplanktonic fraction, while the nanoplanktonic one, which represents a substantial part of the biomass ( $>25 \%$ ), shows a remarkably uniform vertical distribution.

In the Southern Atlantic and in the WeddellScotia Confluence, phytoplankton community is largely dominated by nanoplankton $(<20 \mu \mathrm{m}$, Weber and El-Sayed, 1987; <10 $\mu \mathrm{m}$, Jacques and Panouse, 1991) while, during our cruise at the end of the austral summer, the Strait of Magellan was dominated by pico- and nanoplankton $(<5 \mu \mathrm{m})$ (Marino et al., 1991) with cosmopolitan characteristics (Cabrini and Fonda Umani, 1991; Uribe, 1991; Thomsen et al., 1993).

\subsection{Nutrients}

The vertical distribution of nitrate in the $0-80$ $m$ depth interval along the axis of the Strait is shown at Fig. 8. The main feature regards the high range of nitrate content in the surface layer (1.7-11.4 $\mu \mathrm{M})$. Although the cruise period was late summer, nitrate was never exhausted.

Proceeding eastward from the Pacific entrance, nitrate, salinity and density distribution patterns suggest the presence of five distinct sectors and show the non homogeneity of the physico-chemical environment of the phytoplanktonic communities (Figs. 8 and 9). Cited salinities are from Artegiani et al. (1991).

- The Pacific opening (St. 4), connected directly with the open sea over a relatively shallow sill $(60 \mathrm{~m})$, showed a vertical structure characteristic of a wind mixed coastal ocean (sector A). Salinities higher than 32.00 PSU were observed on the whole water column and nitrate distribution was uniform between surface and $60 \mathrm{~m}$.

- The second sector (B), from Cape Pilar to

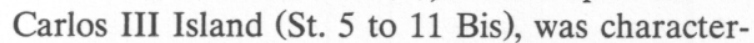
ized by strong vertical gradients of nitrate and density, with eastward increasing intensities. In this sector, heavy rainfalls and runoff lead to a drastic salinity decrease at the surface $(S=$ 27.73-30.09 PSU) and subsurface layers ( $S=$ 28.02-30.50 PSU at $40 \mathrm{~m}$ ). As a consequence, a sharp pycnocline was formed and a quite constant nitrate dilution was always strictly correlated with the stable surface mixed layer. Such features are typical of a high runoff fjord.

- The third sector (C), from Carlos III Island to Cape Froward, showed a pronounced horizontal gradient in nitrate concentrations. At St. 12,

Table 3

Fractionated chl. $a\left(\mathrm{mg} \mathrm{m}^{-2}\right)$ integrated for the euphotic zone at each station

\begin{tabular}{|c|c|c|c|c|c|c|c|c|c|c|c|c|c|}
\hline stat. & 4 & 7 & 9 & 10 & $11 \mathrm{Bis}$ & 12 & 14 & 16 & 17 & 18 & 20 & 22 & 23 \\
\hline Tot. & 13.66 & 13.43 & 19.31 & 18.93 & 10.13 & 17.29 & 29.21 & 30.31 & 51.48 & 46.63 & 33.94 & 14.79 & 29.52 \\
\hline$>10 \mu \mathrm{m}$ & 4.31 & 0.74 & 0.74 & 0.39 & 0.47 & 0.68 & 0.44 & 0.62 & 0.79 & 0.64 & 1.48 & 5.75 & 17.85 \\
\hline $10-2 \mu \mathrm{m}$ & 3.46 & 3.94 & 8.23 & 6.15 & 4.33 & 4.97 & 8.84 & 7.94 & 15.69 & 17.49 & 8.60 & 4.11 & 6.10 \\
\hline $2-0.2 \mu \mathrm{m}$ & 5.93 & 8.76 & 10.34 & 12.40 & 5.33 & 11.64 & 19.92 & 21.75 & 35.00 & 28.51 & 23.85 & 4.93 & 5.58 \\
\hline$\%>10 \mu \mathrm{m}$ & 31.6 & 5.5 & 3.8 & 2.1 & 4.6 & 3.9 & 1.5 & 2.0 & 1.5 & 1.4 & 4.4 & 38.9 & 60.5 \\
\hline$\% 10-2 \mu \mathrm{m}$ & 25.3 & 29.3 & 42.6 & 32.5 & 42.7 & 28.7 & 30.3 & 26.2 & 30.5 & 37.5 & 25.3 & 27.8 & 20.7 \\
\hline$\% 2-0.2 \mu \mathrm{m}$ & 43.4 & 65.2 & 53.5 & 65.5 & 52.6 & 67.3 & 68.2 & 71.8 & 68.0 & 61.1 & 70.3 & 33.3 & 18.9 \\
\hline
\end{tabular}



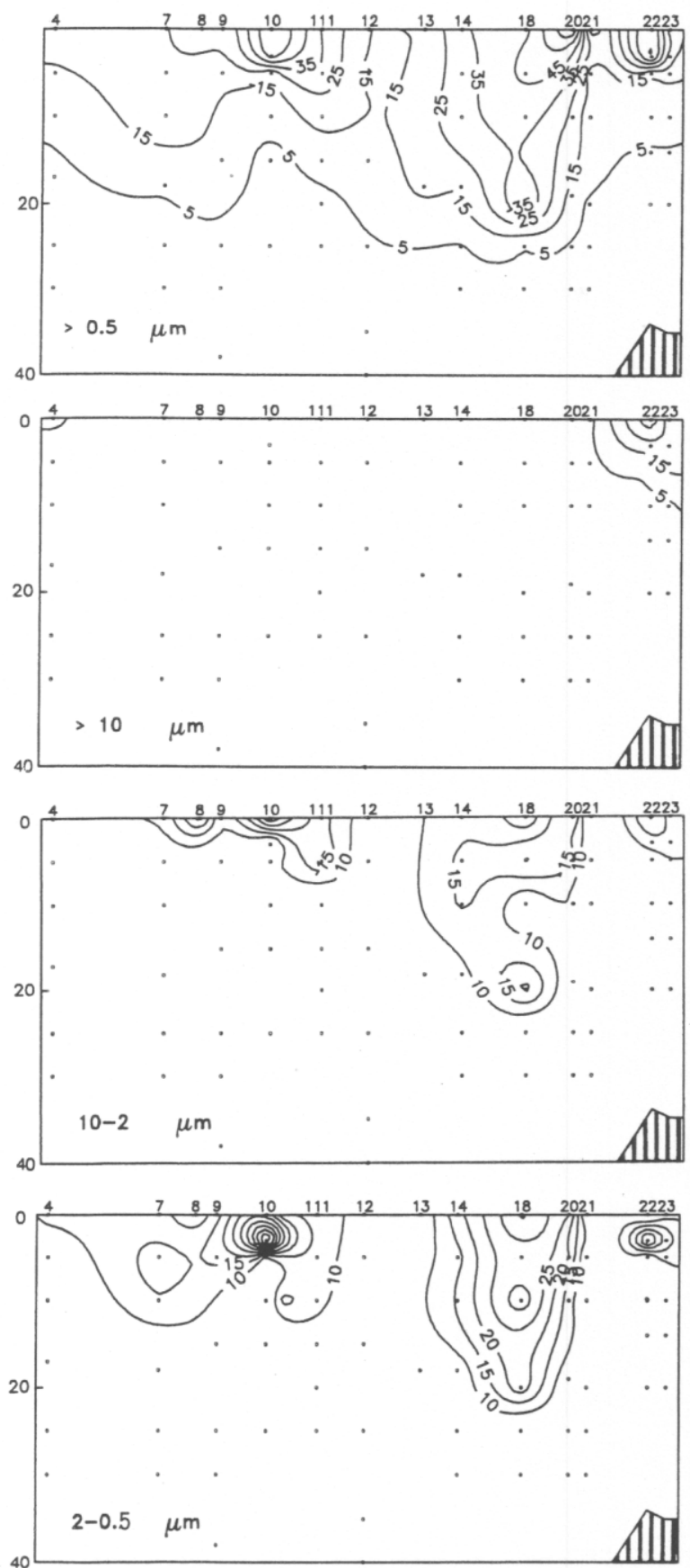

Fig. 6. Distribution of Chl. $a$ (spectrofluorometric determination, $\mu \mathrm{g} / \mathrm{l}$ ) in the upper $40 \mathrm{~m}$ along the axis of the Strait of Magellan (stations 4 to 23 ). Total phytoplankton ( $>0.5 \mu \mathrm{m}$ ), microphytoplankton (>10 $\mu \mathrm{m})$, nanophytoplankton (10-2 $\mu \mathrm{m})$, picophytoplankton $(2-0.2 \mu \mathrm{m})$. values ranged from 7.89 to $9.38 \mu \mathrm{M}$ within the first $150 \mathrm{~m}$, while maximum values were recorded at St. 13 where the vertical distribution was characterized by a slightly increasing trend from the surface $(11.41 \mu \mathrm{M})$ to the bottom $(16.95 \mu \mathrm{M}$ at $460 \mathrm{~m}$ ). At that station, salinity ranged from 30.34 PSU at the surface to 31.16 PSU at $460 \mathrm{~m}$ and density increased only progressively with depth. The high nutrient levels and absence of stratification suggest the presence of a divergence zone inducing the upwelling of nutrient rich water

- The fourth sector (D), from Cape Froward to Isabel Island (Paso Ancho area, from St. 14 to 20 ), is separated from the third one by a sharp decrease in nitrate concentrations, both in the surface and subsurface layers. Nitrate surface concentrations are minimal at St. $18(1.7 \mu \mathrm{M}$ at 0 $\mathrm{m})$. In this sector, fresh water input was minor (surface salinity varied from 30.23 PSU at St. 15 to 30.47 at St. 20) and superficial warming prevailed in generating the vertical stratification. This part of the Strait has the same basic properties as a shallow, stratified inland sea, where stratification is due more to heat than to runoff. The adjacent Bahia Inùtil (St. 16 and 17) presents the same general characteristics.

- The fifth sector (E), from Isabel Island to the Atlantic opening (St. 21 to 23), may be further divided in two sub-sectors: a western one (St. 21), showing relatively high nitrate concentrations along the whole water column (respectively 7.4 and $10.8 \mu \mathrm{M}$ at the surface and at $75 \mathrm{~m}$ ) and an eastern one (St. 22 and 23), occupied by a shallow mixed water mass, with salinity of 30.63-30.74 PSU and reduced nitrate content (5.1-5.8 $\mu \mathrm{M}$ ). In the embayment opening to the Atlantic, tidal mixing in shallow depths prevents any stabilization of the water column and induces a homogeneous distribution of abiotic parameters.

Phosphate concentrations (not presented here) show the same general trends as nitrate.

\subsection{Primary production}

The information on primary production collected during this cruise is reported by Magazzù et al. (1991a), Magazzù et al. (1991b) and by Saggiomo et al. (1991), on which the following considerations are based. 
Fig. 10 shows the spatial variation of total and size-fractionated micro-, nano- and picophytoplanktonic production along the Strait. Integrated values and percent contribution of each fraction, for the euphotic zone ( $1 \%$ of incident PAR), are reported in Table 4.

The maximum of production corresponded to the maximum of biomass and occurred in the
Paso Ancho basin, in front of Punta Arenas, with values in excess of $1 \mathrm{~g} \mathrm{Cm}^{-2} \mathrm{~d}^{-1}$ (St. 18). Only $1-4 \%$ of total primary production was contributed by the microplanktonic fraction, except at St. 4, 22 and 23, where this fraction contributed the 25,39 and $73 \%$, respectively.

Primary production showed the same trend as that of Chl. $a$ and confirms the presence of the
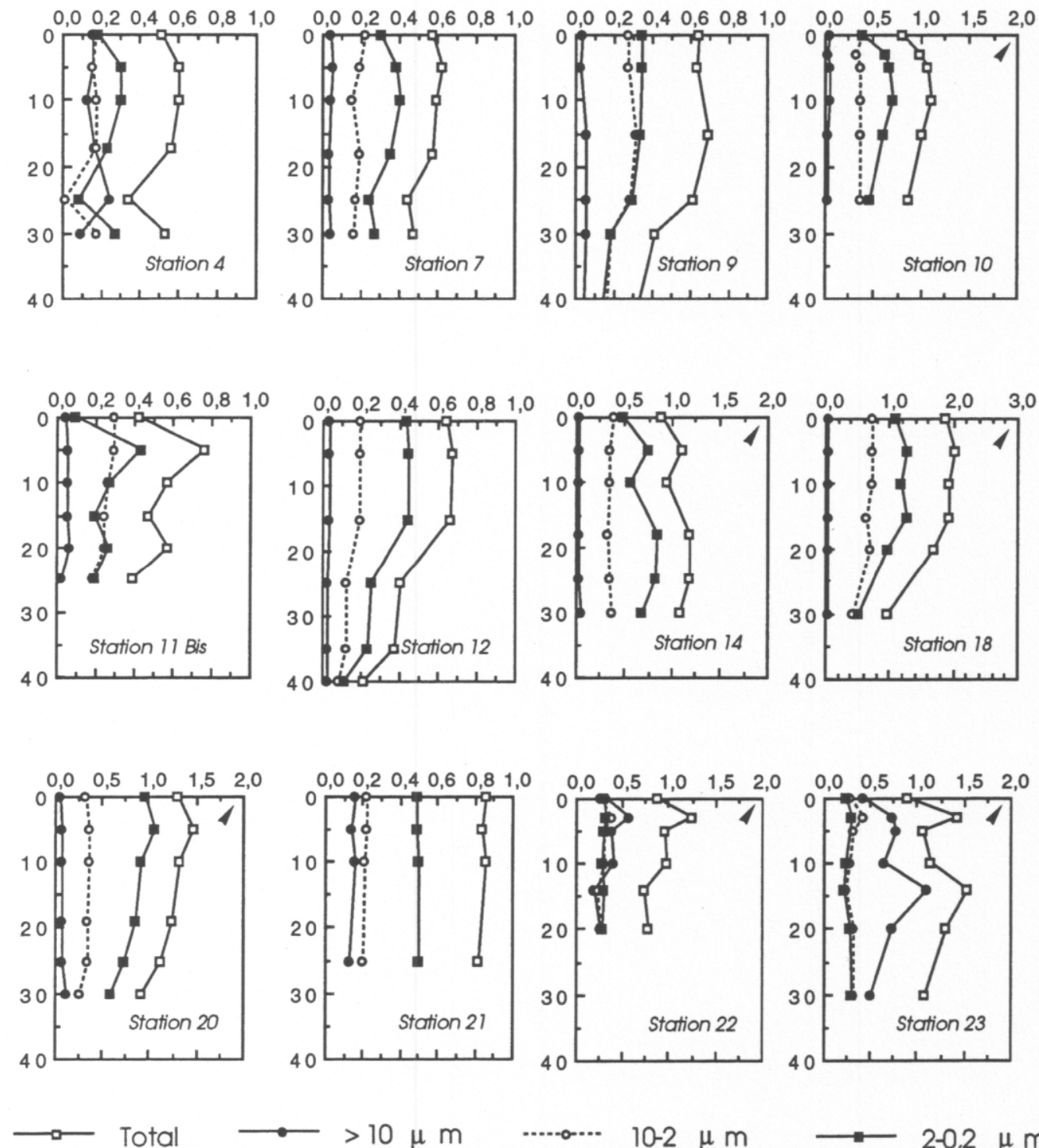

$10-2 \mu \mathrm{m}$

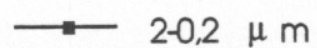

Fig. 7. Vertical distribution ( $0-40 \mathrm{~m})$ of total and size-fractionated chlorophyll $a(>10 \mu \mathrm{m}, 10-2 \mu \mathrm{m}$ and $2-0.2 \mu \mathrm{m})(\mu \mathrm{g} / \mathrm{l})$ at the different stations. 


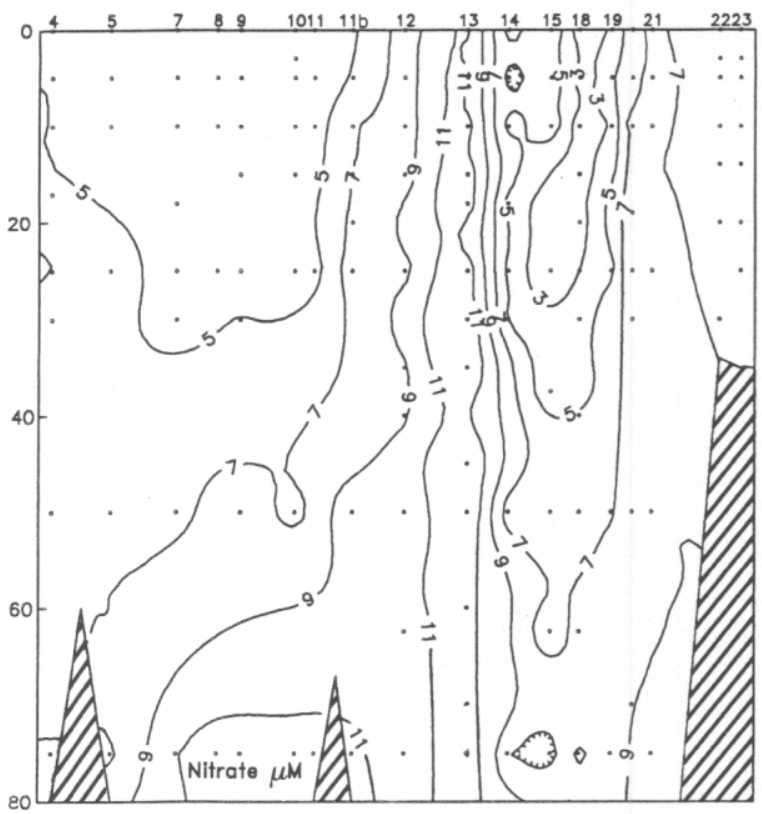

Fig. 8. Distribution of nitrate $(\mu \mathrm{M})$ in the upper $80 \mathrm{~m}$ along the axis of the Strait of Magellan (stations 4 to 23). Data from Catalano and Goffart (1991).

previously mentioned sectors. In particular, the western one (A) is characterized by a high production due to the microplanktonic fraction $(25 \%)$ while the Andean area of the Strait appeared to include two very distinct sectors: a western one (B) where high phytoplankton biomass and primary production were associated with a stable water column generated by a surface layer of low salinity water and an eastern one (C), extending westward to Cape Froward, characterized by high nitrate concentrations, particularly at St. 12 and 13 , where concomitant low values of biomass and primary production were observed. In the Patagonian area, extending from Cape Froward to the Atlantic opening, the sector D, identified by St. 14 to 20 , presented a progressive structuring of the water column reaching its maximum in the central part (St. 18), where the highest levels of primary production were observed. The last sector (E), between the two Narrows (St. 22 and 23), was characterized by a shallow, completely mixed water column $(35 \mathrm{~m})$ and showed high levels of biomasses and primary production, mainly due to the microphytoplanktonic fraction. The two last sectors are clearly separated by an area characterized by high nitrate concentration and low production (St. 21).

At St. 13 and 18, two incubation experiments were carried out on samples from the subsurface chlorophyll maximum, in order to assess the photosynthetic efficiency (Jassby and Platt, 1976) and the potential production. The above stations were selected on the basis of their different hydrographic regimes: an extensive vertical mixing of the whole water column (St. 13) and a clear thermal stratification (St. 18). The two phytoplanktonic communities showed a photosynthetic efficiency of 0.313 and $0.159 \mathrm{mg} \mathrm{C}$ [mg Chl.

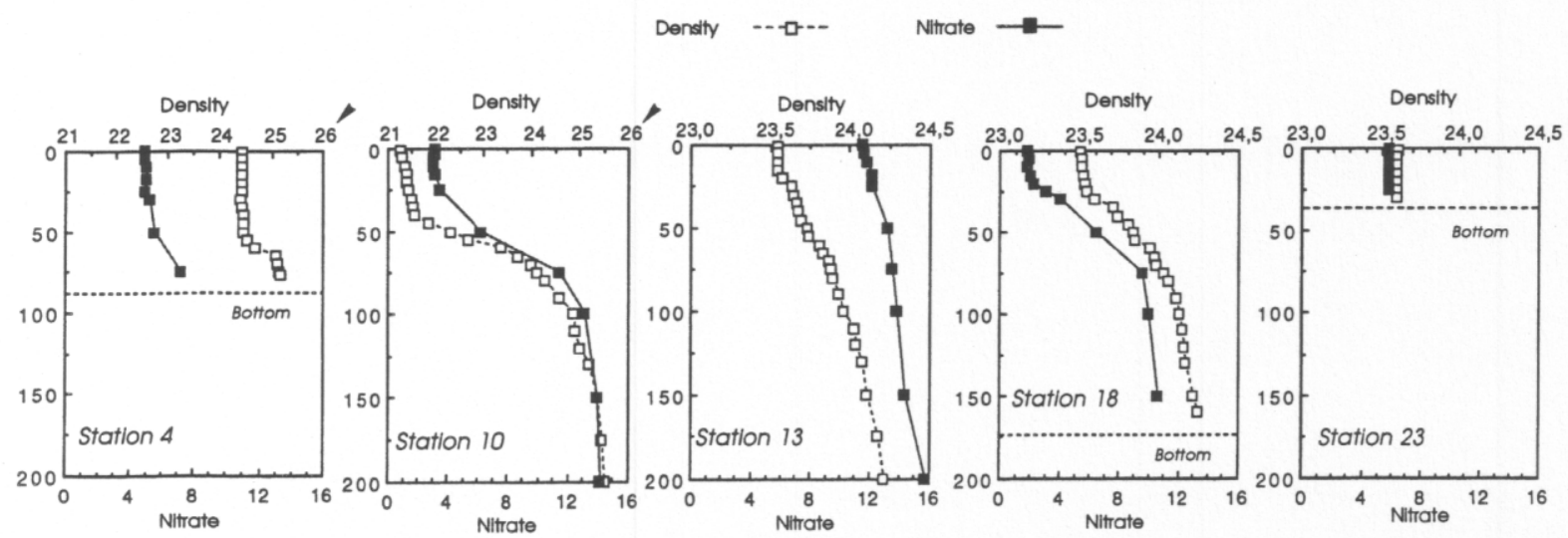

Fig. 9. Vertical distribution (0-200 m) of nitrate $(\mu \mathrm{M})$ and density $\left(\sigma_{\theta}\right)$ at stations $4,10,13,18$ and 23 . Nitrate data from Catalano and Goffart (1991). Density from Artegiani et al. (1991). 



Fig. 10. Distribution of primary production $\left(\mathrm{mg} \mathrm{Cm}^{-3} \mathrm{~d}^{-1}\right)$ in the upper $40 \mathrm{~m}$ along the axis of the Strait of Magellan (stations 4 to 23 ). Total phytoplankton $(>0.5 \mu \mathrm{m})$, microphytoplankton ( $>10 \mu \mathrm{m}$ ), nanophytoplankton (10-2 $\mu \mathrm{m}$ ), picophytoplankton $(2-0.5 \mu \mathrm{m})$. $a]^{-1} \mathrm{~h}^{-1} \mathrm{~W}^{-1} \mathrm{~m}^{-2}$ respectively for St. 13 and St. 18. The phytoplankton communities of St. 13, located in the Andean area (Cape Froward) showed higher efficiency with respect to those of the Patagonian area (St. 18, Paso Ancho), most probably due to the effect of different "light histories" induced by different hydrodynamic regimes.

\subsection{Calculated new production}

In the shallow and stratified part of the Strait, where superficial warming prevails in generating the vertical stratification (Paso Ancho and Bahia Inùtil), the seasonal new production, based on nutrient depletion, has been estimated. The term "depletion" is used in the same sense as by Jennings et al. (1984) and Nelson and Smith (1986). In this context, it means the amount of nitrate removed from the water column during the ongoing growth season and must be distinguished from the notion of very low concentrations, limiting phytoplankton growth (Goeyens et al., 1991).

We estimated algal new production in St. 16, 17 and 18 (Fig. 1), where the water column stratification, the decrease in the nitrate concentrations within the euphotic layer and the high values of primary production indicate a long residence time of the water masses (Fig. 11).

Moreover, the existence of a strong pycnocline allowed the assumption that little or no vertical mixing was taking place between the surface and deeper layers and that the local rate of change in nitrate concentration in the surface layer was not affected by the action of tides.

Dilution of the surface layer by rainfalls and runoff could cause an apparent depletion of nitrate in the mixed layer. However, the surface salinity was within $1.5 \%$ of the salinity of the water situated at $100 \mathrm{~m}$, indicating that dilution effects were negligible.

Assuming that total new nutrient input is due to the winter mixing and that the nitrate concentration measured below the pycnocline, at $100 \mathrm{~m}$ depth, represents the concentration of the mixed layer at the end of the winter, the nitrate content of the water column was computed at each sta- 
Table 4

Fractionated primary production $\left(\mathrm{mg} \mathrm{C} \mathrm{m}^{-2} \mathrm{~d}^{-1}\right)$ integrated for the euphotic zone at each station

\begin{tabular}{|c|c|c|c|c|c|c|c|c|c|c|c|c|c|}
\hline Stat. & 4 & 7 & 9 & 10 & 11Bis & 12 & 14 & 16 & 17 & 18 & 20 & 22 & 23 \\
\hline Tot. & 194.61 & 394.68 & 360.51 & 363.52 & 418.91 & 275.29 & 583.17 & 1169.93 & 910.85 & 1004.90 & 647.76 & 416.46 & 251.58 \\
\hline$>10 \mu \mathrm{m}$ & 48.56 & 17.68 & 7.55 & 8.98 & 11.60 & 9.06 & 11.45 & 36.64 & 11.87 & 9.24 & 13.44 & 160.91 & 182.99 \\
\hline $10-2 \mu \mathrm{m}$ & 58.40 & 131.98 & 102.80 & 117.75 & 185.16 & 111.22 & 289.57 & 402.94 & 476.35 & 329.99 & 251.18 & 97.74 & \\
\hline $2-0.5 \mu \mathrm{m}$ & 87.74 & 244.96 & 250.16 & 236.64 & 222.06 & 154.97 & 281.21 & 730.61 & 422.64 & 665.63 & 309.14 & 157.63 & \\
\hline$\%>10 \mu \mathrm{m}$ & 25.0 & 4.5 & 2.1 & 2.5 & 2.8 & 3.3 & 2.0 & 3.1 & 1.3 & 0.9 & 2.13 & 8.6 & 72.7 \\
\hline$\% 10-2 \mu \mathrm{m}$ & 30.0 & 33.4 & 28.5 & 32.4 & 44.2 & 40.4 & 49.7 & 34.4 & 52.3 & 32.8 & 38.8 & 23.5 & \\
\hline$\% 2-0.5 \mu \mathrm{m}$ & 45.1 & 62.1 & 69.4 & 65.1 & 53.0 & 56.3 & 48.2 & 62.4 & 46.4 & 66.2 & 47.7 & 37.8 & \\
\hline
\end{tabular}

tion for both the end of winter and the end of summer, at the time of the cruise. The differences, representing the nitrate removal by new production (Dugdale and Goering, 1967; Codispoti et al., 1991; Minas, 1992), were converted to carbon using the Redfield ratio (Redfield et al., 1963) (Table 5). The obtained values, ranging from $22 \mathrm{~g} \mathrm{C} \mathrm{m}^{-2}$ at St. 16 to $32 \mathrm{~g} \mathrm{C} \mathrm{m}^{-2}$ at St. 17, provide an estimation of the new primary production integrated through the seasonal cycle.

On the basis of the data of Iriarte et al. (1993), collected during the austral spring 1990 in the same area and showing the onset of the phytoplanktonic bloom at the end of October-beginning of November, the "daily average new production" has been computed using a production period of 130 days, from October 20 to February 28 (Table 5).

Although a number of uncertainties are inherent to this approach, the comparison between the daily average new production and the total primary production, measured at the time of the cruise by ${ }^{14} \mathrm{C}$ uptake, shows that total production exceeds daily average new production by more

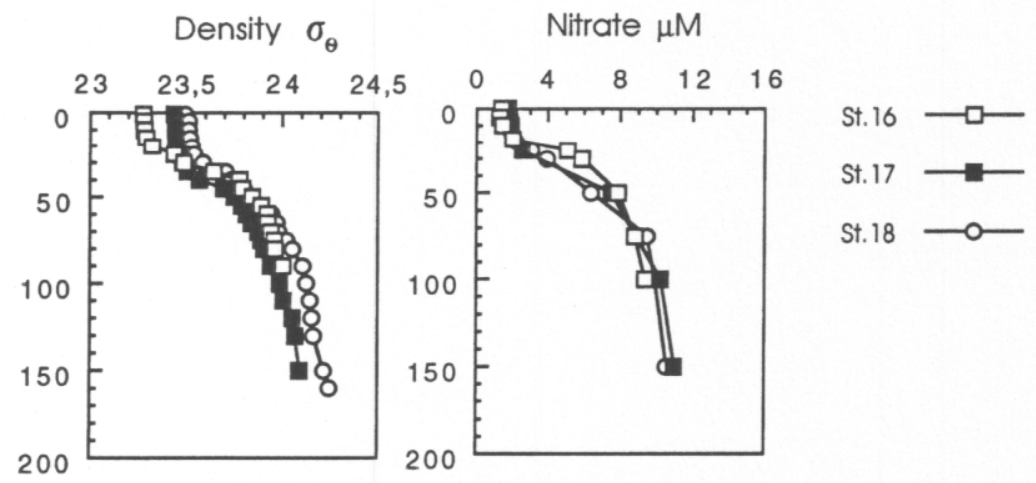

Fig. 11. Vertical distribution $(0-150 \mathrm{~m})$ of nitrate $(\mu \mathrm{M})$ and density $\left(\sigma_{\theta}\right)$ at stations 16,17 (Bahia Inutil) and 18 (Paso Ancho). Nitrate data from Catalano and Goffart (1991). Density from Artegiani et al. (1991).

Table 5

Comparison between calculated new production and measured ${ }^{14} \mathrm{C}$ uptake in Bahia Inùtil (St. 16 and 17) and in Paso Ancho (St. 18)

\begin{tabular}{lllll}
\hline Station & $\begin{array}{l}\text { Seasonal new production } \\
\text { (from NO3 depletion) }\end{array}$ & $\begin{array}{l}\text { Daily average new production } \\
\text { (time interval of } 130 \mathrm{~d})\end{array}$ & $\begin{array}{l}\text { Daily }{ }^{14} \mathrm{C} \text { total production integrated } \\
\text { for the euphotic zone }\end{array}$ \\
\cline { 2 - 5 }$\left(\mathrm{g} \mathrm{C} \mathrm{m}^{-2}\right)$ & $\left(\mathrm{g} \mathrm{C} \mathrm{m}^{-2} \mathrm{~d}^{-1}\right)$ & Day & $\left(\mathrm{g} \mathrm{C} \mathrm{m}^{-2} \mathrm{~d}^{-1}\right)$ \\
\hline 16 & 22.025 & 0.173 & $27 / 02$ & 1.170 \\
17 & 32.124 & 0.247 & $28 / 02$ & 0.911 \\
18 & 30.231 & 0.233 & $28 / 02$ & 1.005 \\
\hline
\end{tabular}


than a factor of 3.5. This observation could support the idea that, in Paso Ancho and Bahia Inùtil, a large fraction of phytoplankton meets its nitrogen needs by taking up ammonium, though nitrate is not exhausted. Moreover, the predominance of the picophytoplanktonic fraction (Table 3), observed in Paso Ancho and Bahia Inùtil, supports the idea that this part of the Strait runs mainly on regenerated nutrients.

\subsection{Pigments detected by HPLC}

During the last decade, photosynthetic pigments have proved to be extremely useful biotracers for elucidating composition, transformation and degradation of phytoplankton. While Chl. $a$ is universally used as an indicator of phytoplankton biomass, other chlorophylls and carotenoids are powerful chemotaxonomic biomarkers (Williams and Claustre, 1991). Obviously, HPLC analysis do not allow to bypass taxonomic investigations but provide useful biological tracers of water masses. Moreover, the physiological state of phytoplankton populations and the grazing pressure can be assessed by measuring specific Chl. $a$ degradation products, mainly phaeophytin $a$, phaeophytin $a$-like, chlorophyllids and phaeophorbids (Bidigare et al., 1986; Klein and Sournia, 1987).

The spatial distribution along the Strait of Magellan of dominant phytopigments and their degradation products, accurately separated and quantified by HPLC, is presented for the $0-80 \mathrm{~m}$ depth interval. For each pigment, its specificity for algal types, physiological state of phytoplankton and degradation processes is commented.

Chlorophyll $a$ is present in all autotrophic organisms, except in Prochlorophytes, where it is replaced by di-vinyl Chl. $a$ (Chisholm et al., 1988). All along the Strait, moderate concentrations of Chl. $a(>250 \mathrm{ng} / \mathrm{l})$ were found in surface waters (Fig. 12). The Chl. $a$ maximum was generally at the surface and the biomass declined with increasing depth, except in the Paso Ancho area, the richest in terms of Chl. $a$, where maxima ( 800 to $1100 \mathrm{ng} / \mathrm{l})$ were located between 5 and $25 \mathrm{~m}$ (St. 18 and 19). Only in this sector significant concentrations were found down to $80 \mathrm{~m}$, below
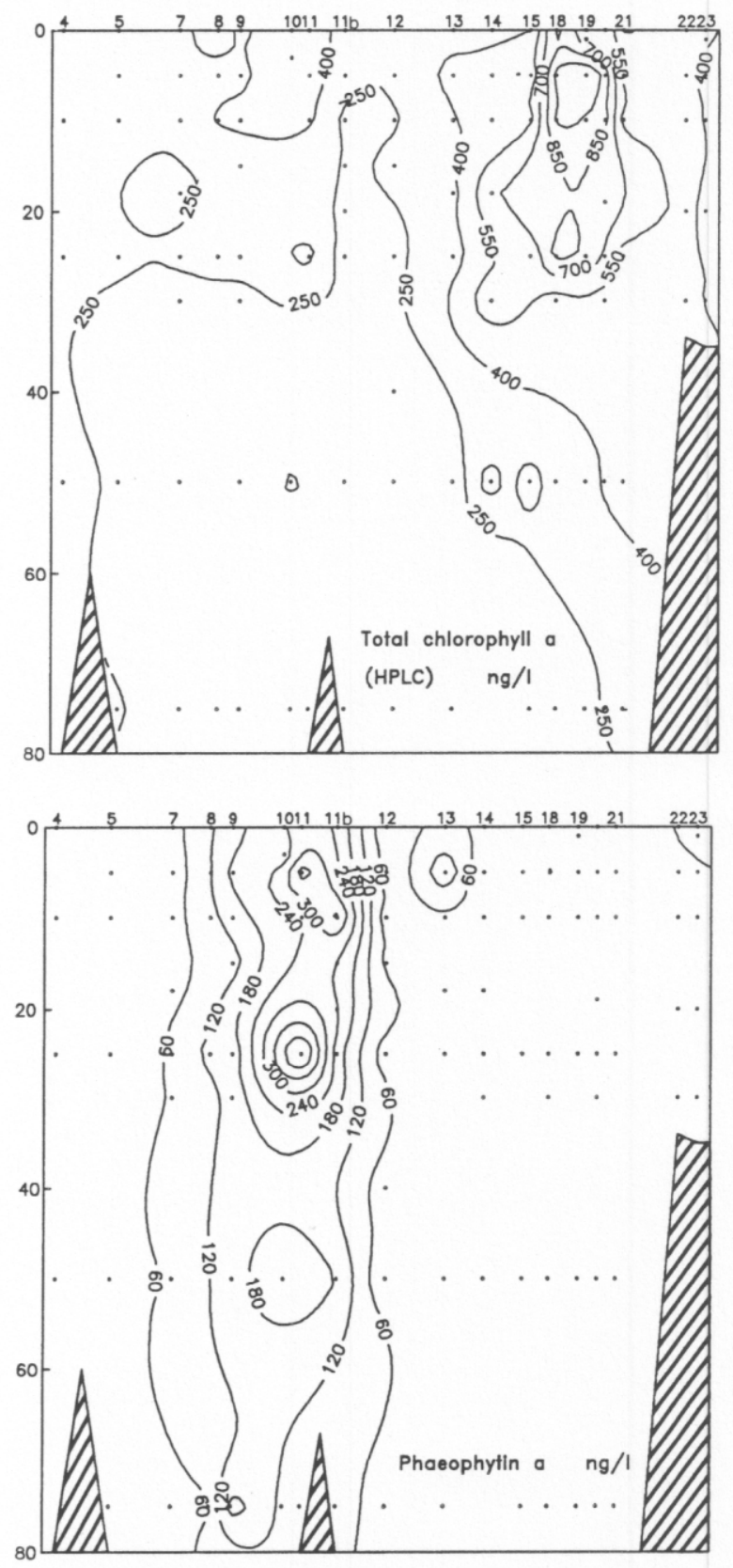

Fig. 12. Distribution of chlorophyll $a$ and phaeophytin $a$ (HPLC, $\mathrm{ng} / \mathrm{l}$ ) in the upper $80 \mathrm{~m}$ along the axis of the Strait of Magellan (stations 4 to 23 ).

the euphotic layer. East of Carlos III Island, at St. 11 Bis, the lowest Chl. $a$ concentrations $(<250$ $\mathrm{ng} / \mathrm{l}$ ) occurred along the whole water column. 
Two types of phaeopigments are considered here: phaeophytins and phaeophorbids. Phaeophytin $a$ is formed by the loss in the phytoplanktonic cell of the magnesium atom (Shuman and Lorenzen, 1975), while phaeophytin $a$-like is generally found in fecal pellets containing uncompletely digested cells (Engelkes, 1985; Klein and Sournia, 1987; Vernet and Lorenzen, 1987). Phaeophytin $a$-like seems to occur mainly during superfluous feeding conditions and is attributable to Copepods as well as to other herbivorous organisms. Moreover, the relative proportion of phaeophytin $a$ and phaeophytin $a$-like varies probably with the residence time of plant material in the zooplankton digestive system (Bidigare et al., 1986).

During this investigation, significant amounts of phaeophytin $a$ (60 to $500 \mathrm{ng} / \mathrm{l}$ ) were clearly restricted to Paso Largo, from St. 8 to St. 11 Bis (Fig. 12) and were followed, eastwards, by a drastic drop of concentrations between St. 11 Bis and 12. Vertical distribution of phaeophytin $a$ was quite homogeneous along the water column and significant concentrations were found down to 80 m.

Phaeophytin $a$-like showed a distribution quite similar to that of phaeophytin $a$ (Fig. 13). However, maximum values were found at St. 10 and the horizontal gradients were less pronounced than those of phaeophytin $a$. A smaller patch of phaeophytin $a$-like was observed around $50 \mathrm{~m}$ to the west of the Second Narrows (St. 21).

In Paso Largo, the distribution patterns of phaeophytin $a$ and phaeophytin $a$-like suggest that phytoplankton produced in the upper layers of the water column was not completely consumed by herbivores. In this section of the Strait, cellular senescence and superfluous feeding appear to be two of the main causes involved in the degradation of phytoplankton that was transported below the euphotic layer by sinking, active transport or downwelling mechanisms. Moreover, the observed high concentrations in phaeophytin $a$ and phaeophytin $a$-like are surprising for the marine environment where these pigments account usually for a small fraction of the total pigment content (Bidigare et al., 1986; Vernet and Lorenzen, 1987). The correlation between
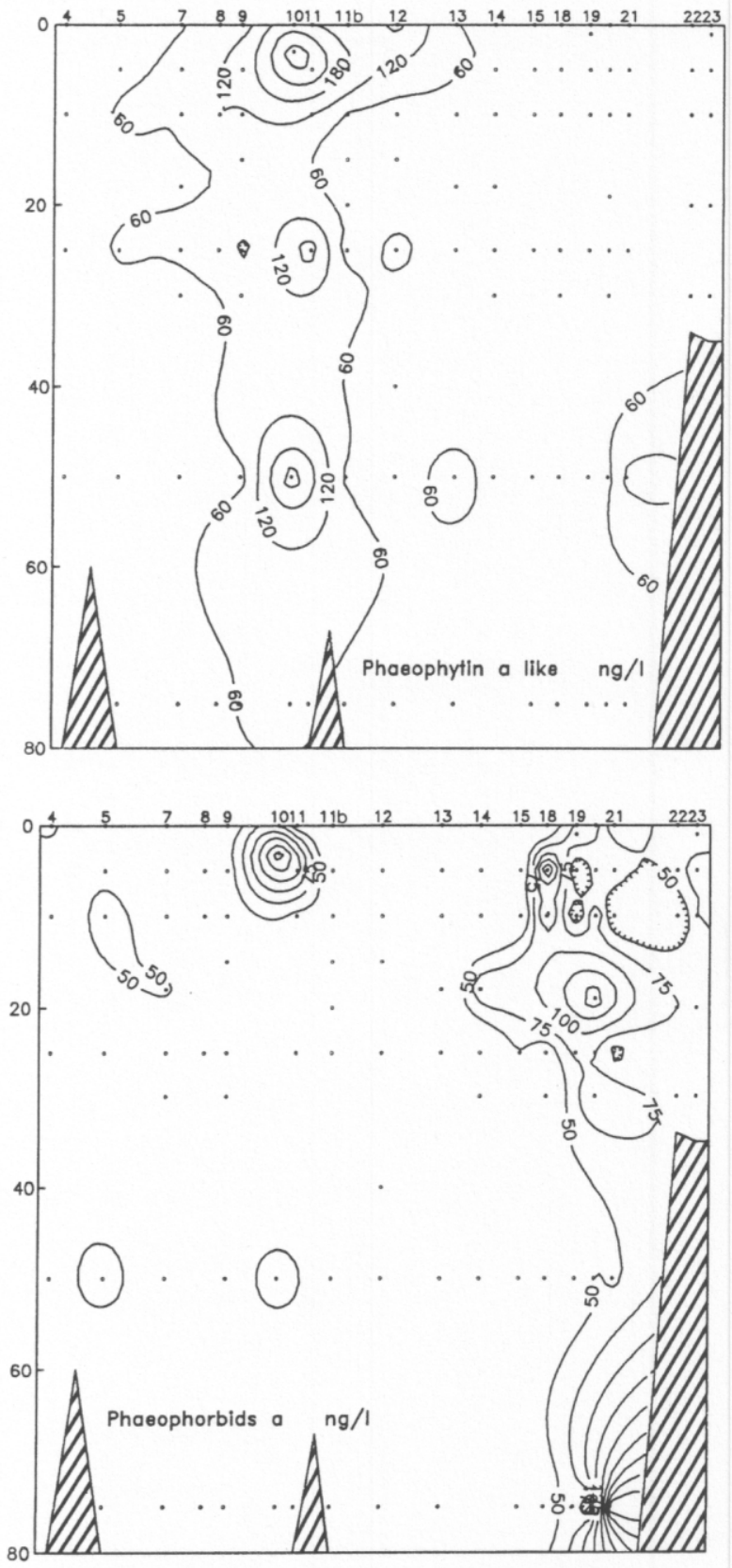

Fig. 13. Distribution of phaeophytin $a$-like and phaeophorbids $a$ (HPLC, $\mathrm{ng} / \mathrm{l}$ ) in the upper $80 \mathrm{~m}$ along the axis of the Strait of Magellan (stations 4 to 23).

the highest concentrations in phaeophytin $a$ and phaeophytin $a$-like and the surface minimum salinities (27.70 PSU-27.88 PSU; Artegiani et al., 
1991) at St. 10 and 11 suggests that fresh water run-off could also supply degradated pigments and control their distribution. In this case, the maximum spreading of the fresh water input will have been westward of St. 10 and 11 and, to a much more reduced extent, towards the surface waters of Paso Froward, beyond the sill.

Phaeophorbids $a$ are the major degradation product found in fecal pellets (Jeffrey, 1974; Welschmeyer and Lorenzen, 1985). They are the result of the breakdown of Chl. $a$ (loss of $\mathrm{Mg}^{++}$ and phytol chain) by the enzymatic activity of the zooplankton digestive system. They are apparently not assimilated and can be used as a conservative tag for the detection of ingested phytoplankton by feeding herbivores.

The distribution of phaeophorbids $a$ along the axis of the Strait is given in Fig. 13. From the Pacific entrance to the eastern end of Dawson Island (St. 15), phaeophorbids are present in very low concentrations, except in the surface layer of Paso Largo (St. 10 and 11) where they reach values higher than $50 \mathrm{ng} / \mathrm{l}$. In that sector, the overall range of phaeophytin $a+a$ like: phaeophorbids $a$ ratio is high ( $>1$ ), suggesting that natural senescence and superfluous grazing are the major contributors to Chl. $a$ degradation, although some efficient grazing activity is detected by the presence of phaeophorbids $a$.

From the Paso Ancho area to the western end of the Second Narrows (St. 18 to 23), a large area where phaeophorbids $a$ concentrations in excess of $50 \mathrm{ng} / 1$ is observed, with distinct maxima (> $150 \mathrm{ng} / \mathrm{l})$ occurring both in the upper layers of the water column $(5-30 \mathrm{~m})$ and below the euphotic zone $(75 \mathrm{~m})$. In this part of the Strait, the absence of other Chl. $a$ degradation products in significant concentrations, as well as the correlation between high levels of phaeophorbids and an increase of the phytoplankton biomass, provide evidence of an efficient grazing characteristic of a balanced food chain.

Chlorophyll $b$ is an accessory pigment found in Chlorophytes, Euglenophytes, Prasinophytes and Prochlorophytes (Jeffrey, 1974; Chisholm et al., 1988). It was strictly confined to the inner stations of the Strait (St. 5 to 20), where two areas of high concentrations were identified (Fig. 14). Pro-
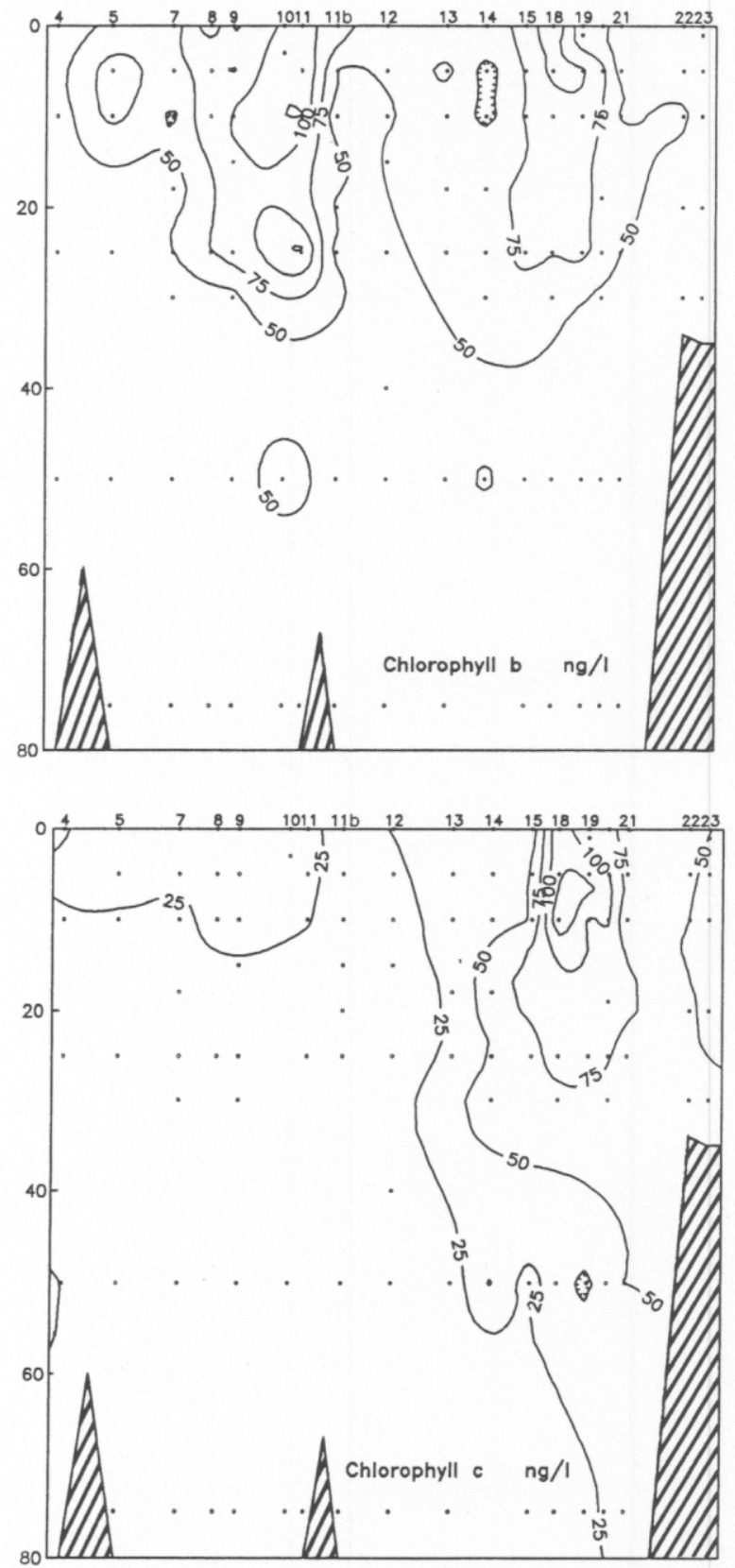

Fig. 14. Distribution of chlorophyll $b$ and chlorophyll $c 1+c 2$ (HPLC, ng/l) in the upper $80 \mathrm{~m}$ along the axis of the Strait of Magellan (stations 4 to 23 ).

ceeding eastward from the Pacific entrance, the first area of high concentration was found in Paso Largo (St. 8 to 11), with maximum values at St. 10 
and 11. The second sector rich in Chl. $b$ was identified by St. 15 to 20, in Paso Ancho, with peak concentrations at St. 18 and 19. In these two areas, values in excess of $75 \mathrm{ng} / \mathrm{l}$ were always restricted to the upper $25 \mathrm{~m}$, except at St. 10 and 14 , where significant amounts of Chl. $b$ were still observed at $50 \mathrm{~m}$, suggesting a downward transport of phytoplankton. Sharp decreases in Chl. $b$ concentrations occurred at St. 11 Bis and 21, marking two zones of discontinuity.

In Paso Largo, the high values of the ratio Chl. $b$ : Chl. $a(>0.25)$ suggest that Chlorophytes dominated the phytoplanktonic community. The confirmation of this hypothesis would offer an additional tool for the taxonomic characterization of the population of this area, markedly dominated by very small coccoid cells $(<3 \mu \mathrm{m})$ (Marino et al., 1991).

The pattern of chlorophylls $c 1+c 2$ (Fig. 14), present in Diatoms, Dinoflagellates, Chrysophytes and Prymnesiophytes was very similar to that of Chl. $a$, already discussed.

Lutein is found in green algae (Chlorophytes, Chrysophytes and some Prasinophytes) (Jeffrey, 1974), while zeaxanthin is characteristic of Cyanobacteria and Prochlorophytes, but occurs also in some other classes (Guillard et al., 1985; Gieskes et al., 1988). Lutein and zeaxanthin coelute and cannot be separated from each other.

Spatial distribution of lutein and/or zeaxanthin (Fig. 15) showed the same general trend as that of $\mathrm{Chl} b$. It was absent at the Pacific opening (St. 4) and east of St. 20. The first area with significant concentrations was observed in Paso Largo, between St. 8 and 11 Bis, with the highest values at St. 10 and 11 (>80 ng/l). Eastward, a strong gradient of decreasing concentrations separated St. 11 Bis from St. 12. The second sector rich in lutein and/or zeaxanthin was located in Paso Ancho, between St. 15 and St. 20, and was followed by another zone of discontinuity between St. 20 and St. 21.

Assuming a constant ratio Chl. $b$ : lutein, as reported for Chlorophytes in the literature (Everitt et al., 1990), the theoric lutein contents have been computed on the basis of the Chl. $b$ measurements. These results, compared with coeluting lutein/zeaxantin values, indicate that
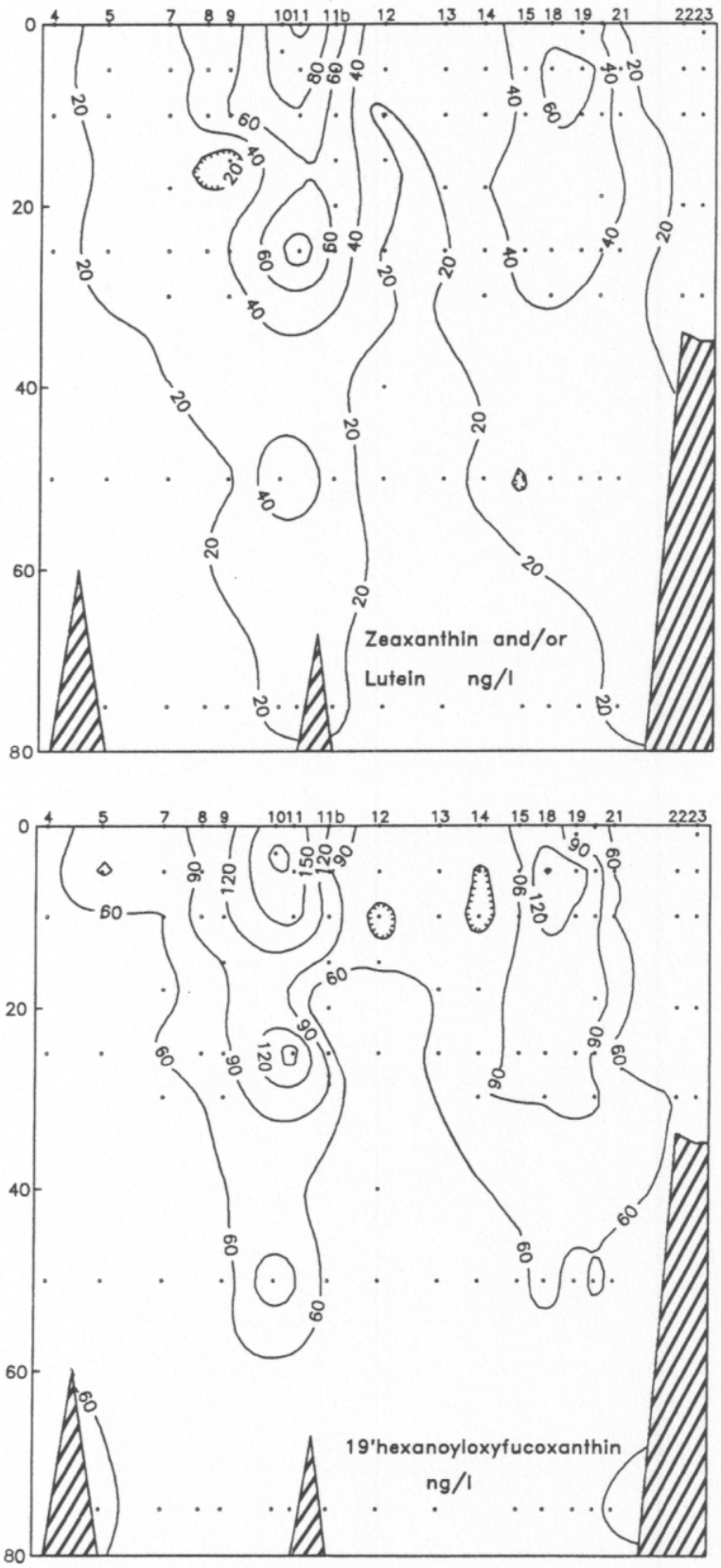

Fig. 15. Distribution of zeaxanthin and/or lutein and $19^{\prime}$ hexanoyloxyfucoxanthin (HPLC, ng/l) in the upper $80 \mathrm{~m}$ along the axis of the Strait of Magellan (stations 4 to 23).

only lutein occurred, suggesting that Cyanobacteria was not an important component of phytoplankton in the Strait of Magellan. Moreover, the 
calculated lutein concentrations sometimes overlapped with the measured ones, which is probably due to the presence of other Chl. $b$ containing organisms, like Euglenoids (that lack lutein) or Prasinophytes (with only small quantities of zeaxanthin).

19 'hexanoyloxyfucoxanthin indicates the presence of Prymnesiophytes but it is also detected in some Dinoflagellates, belonging to the genera Gyrodinium and Gymnodinium (Gieskes and Kraay, 1986). Its distribution showed a pattern similar to those of Chl. $b$ and lutein (Fig. 15).

The coincidence between the spatial distributions of lutein and/or zeaxanthin and 19'hexanoyloxyfucoxanthin suggests the existence of two phytoplanktonic communities, respectively in Paso Largo and in Paso Ancho, well separated by a marked discontinuity at St. 12 and isolated from the population of both openings of the Strait.

Fucoxanthin is a pigment typical of Diatoms, detected also in Chrysophytes and Prymnesiophytes (Jeffrey, 1974; Bjørnland and Liaaen-Jensen, 1989). It showed a rapid change in concentration eastward of St. 11 Bis (Fig. 16). It was the most abundant carotenoid in the Paso Ancho area, with maximum values ( $>200 \mathrm{ng} / \mathrm{l})$ at St. 18 and St. 19, in the upper $25 \mathrm{~m}$. As in the case of Chl. $a$, in these stations, the highest concentrations were confined to the subsurface layers (5-10 $\mathrm{m})$.

Alloxanthin is a typical Cryptomonad pigment (Gieskes and Kraay, 1983) and showed a distribution very similar to that of Chl. $a$ and $c$ (Fig. 16). The highest concentrations ( $>90 \mathrm{ng} / \mathrm{l}$ ) were observed at St. 18, between 5 and $10 \mathrm{~m}$. At St. 12 and 13 , concentrations were insignificant throughout the water column.

An unidentified pigment with the same retention time as cantaxanthin or oscillaxanthin has been found which could be attributed to Cyanobacteria (but also to copepods). Maximum concentrations were observed at the Pacific opening (St. 4), between 10 and $50 \mathrm{~m}$ (Fig. 17). Eastward, concentrations decreased drastically. Along the entire channel, they were unsignificant, except in the subsurface layer at St. 5 to 9,13 and 14. There is no apparent relationship between the distribution of this pigment and that of the others described above.
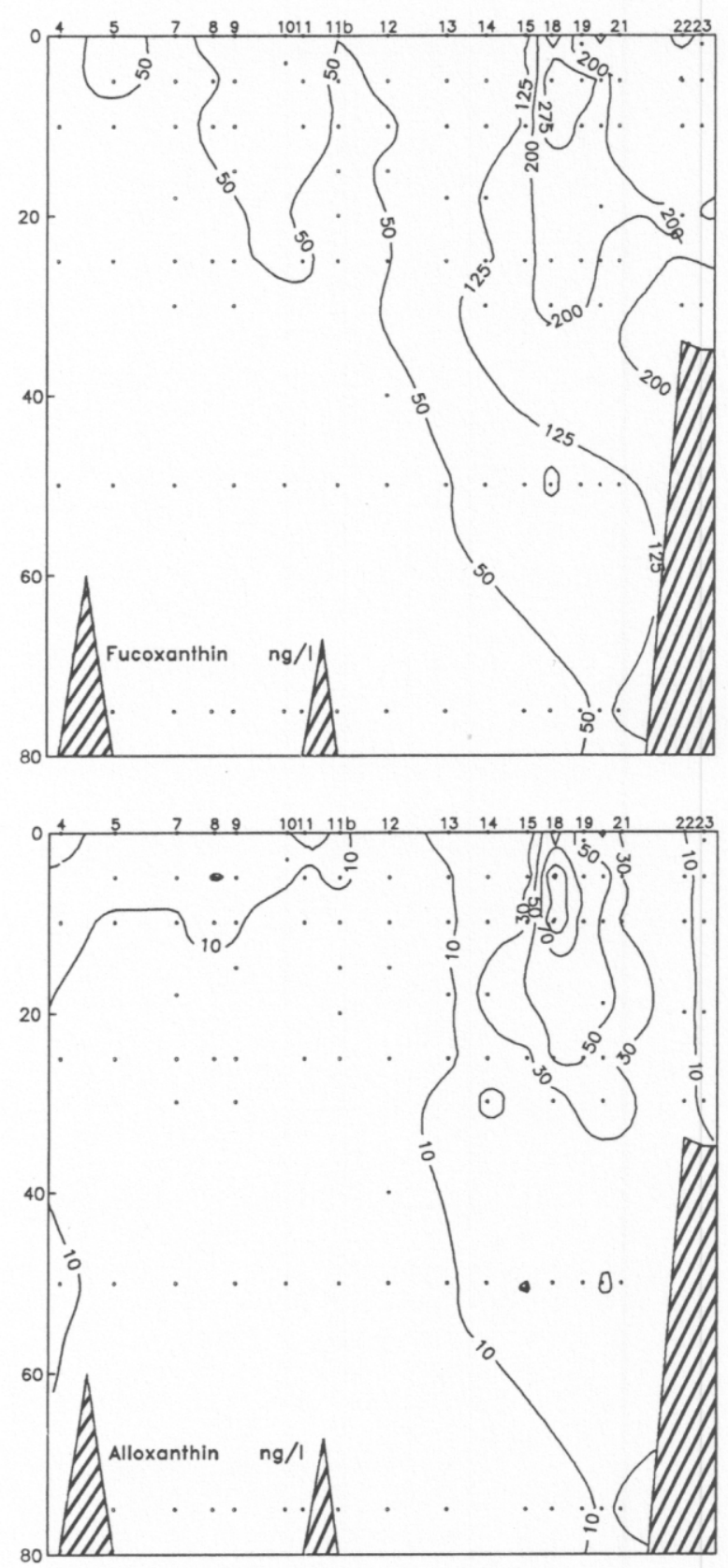

Fig. 16. Distribution of fucoxanthin and alloxanthin (HPLC, $\mathrm{ng} / \mathrm{l})$ in the upper $80 \mathrm{~m}$ along the axis of the Strait of Magellan (stations 4 to 23 ).

Pigment assemblages have emphasized the abrupt changes in the spatial structure of the phytoplanktonic communities. On this basis and 


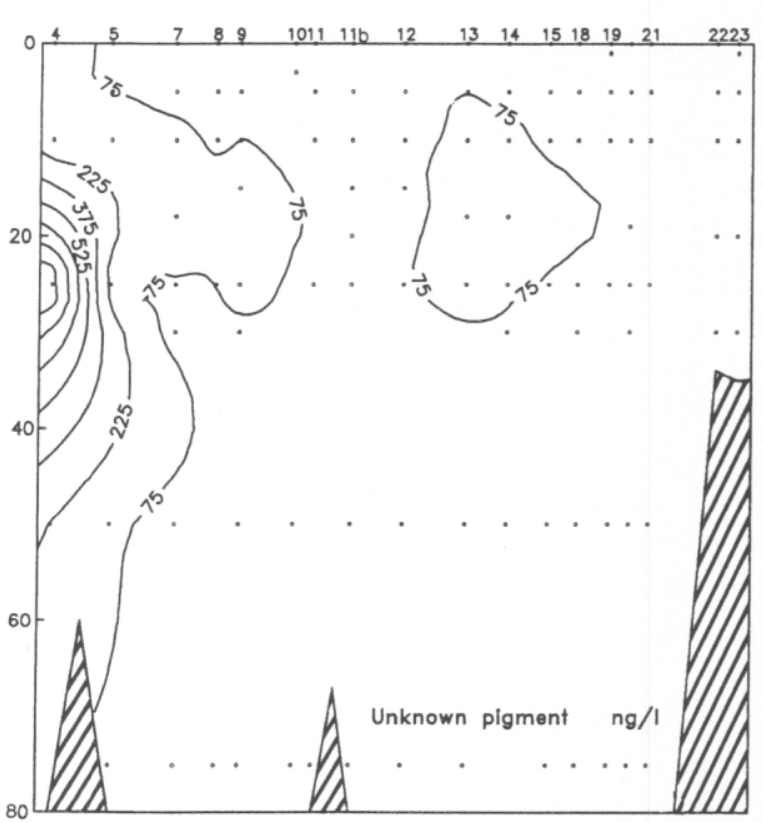

Fig. 17. Distribution of an unknown pigment (HPLC, ng/l) in the upper $80 \mathrm{~m}$ along the axis of the Strait of Magellan (stations 4 to 23).

proceeding eastwards from the Pacific entrance, the presence of different ecological sectors in the Strait of Magellan is confirmed:

- The Pacific opening (St. 4), characterized by an oligotrophic water column and an homogeneous vertical distribution of phytoplanktonic components between the surface and $80 \mathrm{~m}$ (sector A).

- From Cape Pilar to the west of Carlos III Island (St. 5 to St. 11). This area (sector B) was relatively rich of phytoplankton and showed a gradient of increasing concentrations from St. 5 to St. 11. Living phytoplankton was restricted to the upper $30 \mathrm{~m}$ and the community seemed to be dominated by Chlorophytes, Prasinophytes, Prymnesiophytes and/or Gyrodinium- and Gymnodinium-like Dinoflagellates, as suggested эy HPLC investigations. In this sector, the excep:ional distributions of phaeophytin $a$ and phaeoshytin $a$-like and the high range of phaeophytin $z+a$-like: phaeophorbids $a$ ratio indicate that 1atural senescence and superfluous feeding are wo main factors responsible for phytoplankton mortality. Moreover, freshwater runoff and heavy rainfalls induce the formation of a sharp pycnocline and favour the development of more brackish autotrophic populations. Supply of degraded pigments by lateral advection should also be taken into account.

- From the sill located east of Carlos III Island to Cape Froward (St. 11 Bis to St. 12). This sector (C) presented the lowest biomasses for the entire Strait and was clearly separated from Paso Largo by sharp discontinuities affecting all pigments and their degradation products, as well as density and nutrients.

- From Cape Froward to Isabel Island (St. 14 to St. 20). The main feature of this sector (D) was a progressive enhancement of the phytoplankton biomass, culminating at St. 18 and 19. The community was apparently dominated by Diatoms, Cryptomonads and Prymnesiophytes, with only few Chlorophytes, Euglenophytes and Prasinophytes. The quantitatively important phaeophorbids concentrations indicated a tight coupling between an efficient zooplankton grazing and phytoplankton abundance. The presence of significant Chl. $a$ concentrations below the euphotic layer, suggests an active downward transport by physical processes like sedimentation or advection.

- From Isabel Island to the western end of the First Narrows (St. 21 to 23). This sector (E), separated from the fourth one by sharp discontinuities, showed low active Chl. $a$ concentrations distributed throughout the water column and was probably dominated by Diatoms.

\section{Final considerations}

Measurements of fractionated Chl. $a$ and primary production, together with pigment HPLC analysis, have revealed clearcut changes in the structure of phytoplanktonic communities of the Strait of Magellan. Proceeding eastwards from the Pacific entrance, five sub-systems have been identified in relation with the diverse land and sea forcing factors, evidenced by density and nitrate distribution: (A) an oligotrophic, wind mixed coastal area, at the Pacific opening; (B) a high 
runoff fjord, from Cape Pilar to Carlos III Island; (C) a divergence zone, from Carlos III Island to Cape Froward; (D) a shallow, stratified inland sea, where stratification is due more to heat than to runoff, from Cape Froward to Isabel Island (Paso Ancho area), (E) a shallow tidally mixed system, from Isabel Island to the western end of the First Narrow. Along the entire channel, although the cruise period was late summer, nitrate was never exhausted.

On the basis of the size distribution of producers, a first separation between the external sectors of the Strait (A and E) and the internal ones (B, C and D) can be made. The microphytoplanktonic fraction is confined to the Pacific opening (A) and to the embayment between the two Narrows $(\mathrm{E})$ while in the internal sectors $(\mathrm{B}, \mathrm{C}$ and D) phytoplankton communities are dominated entirely by very small cells $(<5 \mu \mathrm{m})$, suggesting that sectors $\mathrm{A}$ and $\mathrm{E}$, on one side, and $\mathrm{B}, \mathrm{C}$ and $\mathrm{D}$, on the other, have different biological dynamics. In addition, the cosmopolitan characteristics of the phytoplankton of the internal sectors underline the peculiarity of the communities of the Strait.

Within the internal sectors (B, C and D), although the phytoplankton communities show a rather uniform dimensional structure, the distributional patterns of pigments and the associated primary production point to a high spatial heterogeneity of primary producers. Each identified sub-system appears characterized by different physical and ecological properties.

The highest levels of phytoplankton pigments and production are associated primarily with the sectors where vertical stability causes the retention of phytoplankton in the euphotic zone. Vertical stratification is induced by runoff and the heavy rainfalls in the sector B (Andean area, Paso Largo) and by superficial warming in the sector D (Patagonian region, Paso Ancho). In the Paso Largo area, the phytoplankton communities seem dominated by Chlorophytes, Prasinophytes, Prymnesiophytes and/or Gyrodinium and Gymnodinium-like Dinoflagellates, as suggested by the information provided by the HPLC analyses and a lateral advection of freshwater could favour the development of a relatively brackish autotrophic population. Moreover, the probable presence of superfluous feeding activities, as shown by the exceptional distribution of phaeophytin $a$ and phaeophytin $a$-like, indicates a reduced degradation of phytoplankton and characterizes a poorly efficient system. On the contrary, in Paso Ancho, the main feature regards the occurrence of a phytoplankton community, presumably dominated by Diatoms, Cryptomonads and Prymnesiophytes, that is efficiently grazed by herbivorous zooplankton.

From Carlos III Island to Cape Froward (sector C), an area characterized by the presence of frontal structures, low biomass and production are observed, in spite of the high nitrate content of the water column. Because of the lack of vertical stratification, the phytoplankton communities are submitted to a regime of light limitation.

The abrupt change observed in the pigment assemblages between Paso Largo (sector B) and the area to the east of Carlos III Island (sector C) underline the absence of large scale exchanges within the Andean part of the channel. On the other hand, the pigment isolines present a domelike pattern corresponding to St. 12 and 13 (sector $\mathrm{C}$ ), providing some additional evidence of a frontal structure associated with a divergence, in coincidence with the openings of Barbara Channel, Seno Pedro and Magdalena Channel. In Paso Ancho (sector D), the presence of a phytoplankton community entirely different from that of the other sectors, together with a strong pycnocline and an important decrease of nitrate within the euphotic layer, suggests that a hydrodynamical system confines and supports the local population by increasing the residence time of the water masses.

In the central part of Paso Ancho (St. 18) and in the Bahia Inùtil (St. 16 and 17), the calculated new production supports the idea of a seasonal biological consumption. In these two areas it seems that the vertical structure of the whole water column is characterized by little or no vertical mixing.

Moreover, although tidal currents are important in the Patagonian branch of the Strait, distributions of biological, chemical and physical pa- 
rameters exclude the hypothesis of a westward strong residual current of Atlantic origin during the stratified period.

On the other hand, our considerations on the Pacific origin of the waters of the Strait of Magellan during the austral summer are supported by the mentioned observation by Glorioso (1987) of a cold and low salinity water mass of Magellan origin just south of the Gulf of San Jorge on the Argentinian shelf.

At the light of the above considerations, the term periantarctic, so far utilized in this paper for characterizing the Strait of Magellan, appears to have geographic significance, as the hydrographical and ecological properties identifying the different sectors point to a subarctic rather than a periantarctic character of the system.

Further investigations, with finer spatial scales and additional sampling in the lateral channels and on the Atlantic shelf, would yield the information necessary for drawing an outline of this poorly known area and allow the quantification of the relative importance of the two Oceans in structuring the ecosystem of the Strait.

\section{Acknowledgements}

This work was carried out in the frame of the Italian National Programme for Antarctica (PNRA), whose support in the field and laboratory activities is gratefully acknowledged. The work of A. Goffart and J.H. Hecq was also supported by the Belgian Scientific Research Programme on Antarctica, funded by the Science Policy Office (Brussels, Belgium), under contract ANTAR II/06. Cordial thanks to Maurizio Ribera d'Alcalà for useful comments and suggestions and to Olga Mangoni and Christine Veeschkens for collaboration to the spectrofluorometric and HPLC analysis.

This paper has substantially benefited from the suggestions of two anonymous referees.

\section{References}

Anonymous, 1981. Turner Designs. Chlorophyll and phaeophytin. Fluorimetric Facts Bull., 101, 11 pp.
Anonymous, 1991. Straits of Magellan Oceanographic Cruise, February-March 1991. Data Report. Part I: Physical, Chemical and Biological Oceanography. Ital. Nat. Sci. Comm. Ant., Genova 1991, 191 pp.

Artegiani, A., Paschini, E. and Andueza Calderon, J., 1991. Physical Oceanography of the Strait of Magellan. In: Anonymous, Straits of Magellan Oceanographic Cruise, February-March 1991. Data Report. Part I: Physical, Chemical and Biological Oceanography. Ital. Nat. Sci. Comm. Ant., Genova 1991, 11-52.

Bidigare, R.R., Frank, J.T., Zastrow, C. and Brooks, J.M., 1986. The distribution of algal chlorophylls and their degradation products in the Southern Ocean. Deep-Sea Res., 33: 923-937.

Bjørnland, T. and Liaaen-Jensen, S., 1989. Distribution patterns of carotenoids in relation to chromophyte phylogeny and systematics. In: J.C. Green, B.S.C. Leadbeater and W.L. Diver (Editors), The Chromophyte Algae: Problems and Perspectives. Clarendon Press, Oxford, pp. 37-60.

Cabrini, M. and Fonda Umani, S., 1991. Phytoplankton populations in the Strait of Magellan. Boll. Oceanol. Teor. Appl., 9(2-3): 137-144.

Campodónico, I.G., Guzmán, L.M. and Lembeye, G.V., 1975. Una discoloracion causada por el ciliado Mesodinium rubrum (Lohman) en Ensenada Wilson, Magallanes. An. Inst. Patagonia, 6: 225-239.

Catalano, G. and Goffart, A., 1991. Dissolved oxygen and nutrients in the Strait of Magellan. In Anonymous: Straits of Magellan Oceanographic Cruise, February-March 1991. Data Report. Part I: Physical, Chemical and Biological Oceanography. Ital. Nat. Sci. Comm. Ant., Genova 1991, pp. 53-66.

Chisholm, S.W., Olsen, R.I., Zettler, E.R., Goericke, R., Waterbury, J.B. and Welschmeyer, H.A., 1988. A novel, free-living prochlorophyte abundant in the oceanic euphotic zone. Nature, 334: 340-343.

Chuecas, L.M., 1980. Contribución al conocimiento de las condiciones hydrograficas de los fiordos de la región magallanica. Bol. Inst. Oceanogr. S. Paulo, 29(2): 95-104.

Codispoti, L.A., Friederich, G.E., Sakamoto, C.M. and Gordon, L.I, 1991. Nutrient cycling and primary production in the marine systems of the Arctic and Antarctic. J. Mar. Syst., 2: 359-384.

Dugdale, R.C. and Goering, J.J., 1967. Uptake of new and regenerated forms of nitrogen in primary productivity. Limnol. Oceanogr., 12: 196-206.

Engelkes, M.M., 1985. Derivaatvorming en afbraak van algenpigmenten door copepodenbegrazing gemeten na scheiding met HPLC. Studentenverslag, N.I.O.Z., Texel, The Netherlands.

Everitt, D.A., Wright, S.W., Volkman, J.K., Thomas, D.P. and Lindstrom, E.J., 1990. Phytoplankton community compositions in the western equatorial Pacific determined from chlorophyll and carotenoid pigment distributions. DeepSea Res., 37: 975-997.

Faranda, F. and Guglielmo, L. (Editors), 1993. Straits of Magellan Oceanographic Cruise, February-March 1991. Data Report. Part II: Physical, Chemical and Biological 
Oceanography. Ital. Nat. Sci. Comm. Ant., Genova 1991, $317 \mathrm{pp}$.

Gieskes, W.W.C. and Kraay, G.W., 1983. Dominance of Cryptophyceae during the phytoplankton spring bloom in the central North Sea detected by HPLC analysis of pigments. Mar. Biol., 7: 179-185.

Gieskes, W.W.C. and Kraay, G.W., 1986. Analysis of phytoplankton pigments by HPLC before, during and after mass occurrence of the microflagellate Corymbellus aureus during the spring bloom in the open northern North Sea in 1983. Mar. Biol, 92: 45-52.

Gieskes, W.W.C., Kraay, G.W., Nontji, A., Setiapermana, D. and Sutomo, 1988. Monsoonal alteration of a mixed and a layered structure in the phytoplankton of the euphotic zone of the Banda Sea (Indonesia): a mathematical analysis of algal pigments fingerprints. Neth. J. Sea Res., 22: 123-137.

Glorioso, P, 1987. Temperature distribution related to shelfsea fronts on the Patagonian Shelf. Cont. Shelf Res., 7(1): 27-34.

Goeyens, L., Sörensson, F., Tréguer, P., Morvan, J., Panouse, M. and Dehairs, F., 1991. Spatio-temporal variability of inorganic nitrogen stocks and upatake fluxes in the Scotia-Weddell Confluence area during November and December 1988. Mar. Ecol. Prog. Ser., 77: 7-19.

Guillard, R.R.L., Murphy, L.S., Foss, P. and Liaaen-Jensen, S., 1985. Synechoccus ssp. as likely zeaxanthin-dominant ultraphytoplankton in the North Atalantic. Limnol. Oceanogr., 30: 412-414.

Guzmán, L.M., Campodónico, I.G. and Hermosilla, J.S., 1975. Estudios sobre un florecimiento toxico causado por Gonyaulax catenella en Magallanes. I. Distribución espacial y temporal de G. catenella. An. Inst. Patagonia, 6: 173-183.

Hansen, H.P. and Grasshoff, K., 1983. Automated chemical analysis. In: K. Grasshoff, M. Ehrhardt and K. Kremling (Editors), Methods of Seawater Analysis, 2nd Ed. Verlag Chemie, Weinheim, pp. 347-379.

Hecq, J.H., Veeschkens, C. and Goffart, A., 1991. Results of phytopigments analysis by HPLC during the oceanographic cruise in the Strait of Magellan (Feb.Mar.1991). In: Anonymous, Straits of Magellan Oceanographic Cruise, February-March 1991. Data Report. Part I: Physical, Chemical and Biological Oceanography. Ital. Nat. Sci. Comm. Ant., Genova 1991, pp. 169-194.

Iriarte, J.L., Uribe, J.C. and Valladares, C., 1993. Biomass of size-fractionated phytoplankton during the spring-summer season in Southern Chile. Bot. Mar., 36: 443-450.

Jacques, G. and Panouse, M., 1991. Biomass and composition of size fractionated phytoplankton in the Weddell-Scotia Confluence area. Polar Biol., 11: 315-328.

Jassby, A.D. and Platt, T., 1976. Mathematical formulation of the relationship between photosynthesis and ligth for phytoplankton. Limnol. Oceanogr., 21: 540-547

Jeffrey, S.W., 1974. Profiles of photosynthetic pigments in the ocean using thin-layer chromatography. Mar. Biol., 26: 101-110.
Jennings, J.C., Gordon, L.I. and Nelson, D.M., 1984. Nutrient depletion indicates high primary productivity in the Weddell Sea. Nature, 309: 51-54.

Klein, B. and Sournia, A., 1987. A daily study of the diatom spring bloom at Roscoff (France) in 1985. II. Phytoplankton pigments composition studied by HPLC analysis. Mar. Ecol. Progr. Ser., 37: 265-275.

Lembeye, G.V., 1981. Estructura del fitoplancton asociado a la presencia del veneno paralitico de los mariscos en Seno Union y areas adyacentes (Magallanes, Chile, 1981). An. Inst. Patagonia, 12: 277-288.

Lembeye, G.V., Guzmán, L.M. and Campodónico, I.G., 1975. Estudios sobre un florecimiento toxico causado por Gonyaulax catenella en Magallanes. III. Fitoplancton asociado. An. Inst. Patagonia, 6: 197-208.

Lembeye, G.V., Guzmán, L.M. and Campodónico, I.G., 1978. Fitoplancton del sector oriental del Estrecho de Magallanes, Chile (5 al 13 de abril de 1976). An. Inst. Patagonia, 9: 221-228.

Magazzù, G. (Editor), 1991. Proceedings of the International Workshop "Aree Subantartiche". Mem. Biol. Mar. Oceanogr., 19, 262 pp.

Magazzù, G. e Decembrini, F., 1990. Produzione del picofitoplancton. In: M. Innamorati, I. Ferrari I, D. Marino and M. Ribera D'Alcalà (Editors), Metodi Nell'Ecologia del Plancton Marino. Nova Thalassia, 11: 245-275.

Magazzù, G., Saggiomo, V. and Decembrini, F., 1991a. Primary production of the Strait of Magellan. In: Anonymous, Straits of Magellan Oceanographic Cruise, February-March 1991. Data Report. Part I: Physical, Chemical and Biological Oceanography. Ital. Nat. Sci. Comm. Ant., Genova 1991: 89-154.

Magazzù, G., Saggiomo, V. and Decembrini, F. 1991b. Primary production and biomass of pico-, nano- and microphytoplankton in the Strait of Magellan (February-March 1991) in: G. Magazzù (Editor), Proceedings of the International Workshop Aree Subantartiche. Mem. Biol. Mar. Oceanogr., 19: 126-130.

Mantoura, R.F.C. and Llewellyn, C.A., 1983. The rapid determination of algal chlorophyll and carotenoid pigments and their breakdown products in natural waters by reversephase high performance liquid chromatography. Anal. Chim. Acta, 151: 297-314.

Marino, D., Sarno, D. and Zingone, A., 1991. Distibution of phytoplankton populations in the Strait of Magellan (February-March 1991) In: G. Magazzù (Editor), Proceedings of the International Workshop Aree Subantartiche. Mem. Biol. Mar. Oceanogr., 19: 147-150.

Medeiros, C. and Kjerfve, B., 1988. Tidal characteristics of the Strait of Magellan. Cont. Shelf Res., 8: 947-960.

Michelato, A., Accerboni, E. and Berger, P., 1991. Current meter observations in the eastern and central sectors of the Strait of Magellan. Boll. Oceanol. Teor. Appl., 9(2-3): 261-271

Minas, H.J., 1992. Estimation of primary production by observation of changes in the mesoscale nitrate field. ICES 1992, Primary Production Symposium, Paper 14. 
Nelson, D.M. and Smith, W.O., 1986. Phytoplankton bloom dynamics of the western Ross Sea ice edge - II Mesoscale cycling of nitrogen and silicon. Deep-Sea Res., 33: 13891412.

Panella, S., Michelato, A., Perdicaro, R., Magazzù, G., Decembrini, F. and Scarazzato, P., 1991. A preliminary contribution to understanding the hydrological characteristics of the Strait of Magellan: Austral Spring 1989. Boll. Oceanol. Teor. Appl., 9(2-3): 107-126.

Pickard, G.L., 1971. Some physical oceanographic feature of inlets of Chile. J. Fish. Res. Bd. Canada, 28: 1077-1106.

Pickard, G.L., 1973. Water structure in Chilean Fjords. In: R. Fraser (comp.) Oceanography of the South Pacific 1972. New Zealand National Commission for UNESCO, Wellington: 1973, pp. 95-104.

Redfield, A.C., Ketchum, B.H. and Richards, F.A., 1963. The influence of organisms on the composition of sea water. In: M.N. Hilled (Editor), The Sea, Ideas and Observations on Progress in the Study of the Seas. Interscience, New York, pp. 26-77.

Saggiomo, V., Magazzù, G., Modigh, M. and Decembrini, F., 1990. Produzione del fitoplancton. In: M. Innamorati, I. Ferrari I, D. Marino and M. Ribera D'Alcalà (Editors), Metodi Nell'Ecologia del Plancton Marino. Nova Thalassia, 11: 231-244.

Saggiomo, V., Decembrini, F. and Magazzù, G., 1991. Photosynthetic efficiency of different phytoplankton size fractions in the Strait of Magellan (February-March 1991) In: G. Magazzù (Editor), Proceedings of the International Workshop Aree Subantartiche. Mem. Biol. Mar. Oceanogr., 19: 131-134.

Shuman, F.R. and Lorenzen, C.J., 1975. Quantitative degra- dation of chlorophyll by a marine herbivore. Limnol. Oceanogr., 31: 449-452.

Thomsen, H.A., Buck, K.R., Marino, D., Sarno, D., Hansen, L.E. and Ostergaard, J.B., 1993. Lennoxia faveolata gen. et sp. nov. (Diatomophyceae) from South America, California, West Greenland and Denmark. Phycologia, 32(4): 278-283..

Uribe, J.C., 1988a. Antecedentes sobre un tercer brote de veneno paralizante de moluscos (VPM) en la region de Magallanes. An. Inst. Patagonia, 18: 97-101.

Uribe, J.C., 1988b. Observaciones sobre algunos fenómenos recurrentes en el fitoplancton de seno Union y bahía Bell (región de Magallanes) y su relacion con la estabilidad de la columna de agua. An. Inst. Patagonia, 18: 103-111.

Uribe, J.C., 1991. Net-phytoplankton distribution in the Strait of Magellan. Boll. Oceanol. Teor. Appl., 9(2-3): 145-150.

Vernet, M. and Lorenzen, C.J., 1987. The relative abundance of phaeophorbide a and phaeophytin a in temperate marine waters. Limnol. Oceanogr., 32: 352-358.

Weber, L.H. and El-Sayed, S., 1987. Contributions of net, nano- and picoplankton to the phytoplankton standing crop and primary productivity in the Southern Ocean. J. Plankton. Res., 9: 973-994.

Welschmeyer, N.A. and Lorenzen, C.J., 1985. Chlorophyll bugdets: zooplankton grazing and phytoplankton growth in a temperate fjord and the Central Pacific Gyres. Limnol. Oceanogr., 30: 1-21.

Williams, R. and Claustre, H., 1991. Photosynthetic pigments as biomarkers of phytoplankton populations and processes involved in the transformation of particulate organic matter at the Biotrans site $\left(47^{\circ} \mathrm{N}, 20^{\circ} \mathrm{W}\right)$. Deep-Sea Res., 38: $347-355$. 